Portland State University

PDXScholar

$12-18-2020$

\title{
The Electronic Hardware Music Subculture in Portland, Oregon
}

James Andrew Hickey

Portland State University

Follow this and additional works at: https://pdxscholar.library.pdx.edu/open_access_etds

Part of the Sociology Commons, and the Urban Studies Commons Let us know how access to this document benefits you.

\section{Recommended Citation}

Hickey, James Andrew, "The Electronic Hardware Music Subculture in Portland, Oregon" (2020). Dissertations and Theses. Paper 5598.

https://doi.org/10.15760/etd.7470

This Thesis is brought to you for free and open access. It has been accepted for inclusion in Dissertations and Theses by an authorized administrator of PDXScholar. Please contact us if we can make this document more accessible: pdxscholar@pdx.edu. 
The Electronic Hardware Music Subculture in Portland, Oregon

by

James Andrew Hickey

A thesis submitted in partial fulfillment of the requirements for the degree of

Master of Urban Studies

Thesis Committee:

Greg Schrock, Chair

Moriah McGrath

Carl Abbott

Portland State University

2020 
Abstract

Music is relatively understudied as a geographic phenomenon, but recently there has been a shift in academic literature to understand the social, cultural and economic factors that determine music and its development in specific places. The purpose of this study is to examine the Electronic Hardware Music Subculture (EHMS) in Portland, why it thrives, and how it is linked to the local cultural economy. To do this, I used semi-structured, long form interviews with key members of the EHMS. These interviews, and my own observations, gave insight into what factors affect the success of members of the EHMS, and how the subculture thrives more generally. Key factors that dictate success for members of the EHMS include: the ability to pursue art for non-commercial reasons, community openness and receptivity to new music, availability of spaces to perform and practice, and the number of institutions that allow for effective development of musical-cultural production. My findings demonstrate that Portland is a unique city in the United States for niche cultural production, as it offers relative affordability, institutional and technological capacity, and cultural consumers that are open to a range of cultural products. My findings suggest that for under researched areas of cultural production in urban areas, access to key cultural producers and institutions is necessary to understand cultural production. 
For planners, policies that emphasize bolstering institutional capacity, and making urban areas livable for artists and musicians can catalyze nascent cultural economies. 


\section{Table of Contents}

Abstract i

Chapter 1: Introduction 2

Chapter 2: Literature Review $\quad 7$

Music in the Urban Environment $\quad 7$

Narrowing the focus: Music and Subcultures 9

The Subcultural Economy 12

Beyond the Cultural Economy 16

Commerce and Music in Tension: Bourdieu and Cultural Capital 18

Chapter 3: Research and Methods 25

Chapter 4: Findings and Discussion 30

Summary of Findings $\quad 30$

Art for Art's Sake and the Non-material motivations of Participants 31

Portland's Affordability and Openness for Artists 39

From Community to Institutions: Portland's Institutional Capacity for the EHMS

$\begin{array}{ll}\text { Table } 1 & 47\end{array}$

Key Institutions 52

S1 52

Portland Community College 56

Pacific Northwest College of Art 60

$\begin{array}{ll}\text { Chapter 5: Conclusion } & 63\end{array}$

$\begin{array}{ll}\text { References } & 70\end{array}$

$\begin{array}{ll}\text { Appendix } & 75\end{array}$

$\begin{array}{ll}\text { Table } 1 & 75\end{array}$

Interview Guide $\quad 77$

$\begin{array}{ll}\text { Final Thematic Codes } & 78\end{array}$ 


\section{Chapter 1: Introduction}

The purpose of this study is to explore the ways in which a specific music subculture thrives in Portland, Oregon, and how it is linked to the city's local culture and economy. A cursory reading of academic literature will reveal a number of investigations into different musical subculture rock, hip hop, jazz, techno, etc. The particular subculture that I will examine in this discussion focuses on music that is created through electronic hardware, including synthesizers and computers. Throughout this paper, I will refer to this subculture, a network of individuals with ties to various spaces, places, performance venues, and various aesthetic and semiotic sensibilities that members share, as the electronic hardware music subculture (EHMS).

The EHMS, as its name suggests, is a music subculture centered around creating electronic, experimental, and dance music through the use of synthesizers, computers (e.g., laptops), and equipment (e.g., turntables; tape machines). Sonically, the music and sound created by members of the EHMS are more diverse than many genres of music, but they almost always depend on the use of electronic technology, rather than acoustic instruments. Music made by members of the EHMS tends to move along one of two aesthetic trajectories. Some members focus on long format, rhythmless, often ambient or experimental compositions. This style of electronic music has its foundation in the '60s and 
'70s progressive synthesizer music of Klause Schulze, Tangerine Dream, Kraftwerk, and Brian Eno and gave way to the then new genres of electronic ambient and new age music in the ' 80 s (Collins and d'Escrivan, 2017). The other broad style of music composed by members of the EHMS is rhythm-centric electronic music, which depends on the use of samplers, drum machines, and turntables, often in combination with computers for arrangement and processing. This style of music can trace its lineage in a similar fashion to '60s electronic music, but came into its own in the ' 80 s techno scene of Detroit. It then spread across major urban areas in the United States and especially Europe, splitting into a number of electronic dance subgenres, such as house, breakbeat, and jungle (Cosgrove, 1988).

An EHMS subculture exists in every large urban city in the United States, with various degrees of development and connections to private and public institutions. In Portland, individuals in the EHMS have connections to a number of institutions. Some of these include $\mathrm{S} 1$, a non-profit, artist run project space and contemporary art center, Control Voltage, an instrument store which sells synthesizer and electronic hardware, Portland Community College (PCC), and various record stores, art institutes, galleries, and sporadically recurrent pop-up dance parties and clubs throughout Portland. Most of the physical spaces connected to the EHMS are in Inner Northeast and Southeast Portland. Spaces 
that focus on raves or dance parties are more prevalent in the current and previously industrial areas of North Portland and Milwaukie.

Demographically, individuals in the EHMS are often between the ages of twenty to forty, and hold jobs in creative industries (e.g., graphic designers, audio/visual technicians, gallery curators). Consistent with prior research on artists and musicians, many individuals in the EHMS are in the "creative class" (Florida, 2014), though some work in the retail and service industries. Like most subcultures, the EHMS shares aesthetic qualities: in terms of fashion, minimal and oversized clothes are commonplace, especially streetwear styles (usually featuring brands like Adidas or Nike), or military styles of clothing. Outfits tend to be minimal (as opposed to the maximal styles of some punk, goth, or rave subcultures). The demographics of the EHMS, mirroring the Portland Demographic at large, tend to be majority white. Men are more likely to be both participants and consumers, however in recent years, as many participants attested, more women and people of color have become involved in the subculture. Among the participants that I interviewed, about one third identified as female.

The reasons for investigating the EHMS are many, and will become clear throughout this study, but can be fundamentally attributed to two complimentary reasons: (1) the effect(s) of the EHMS in Portland on the local economy and 
culture is not well understood, especially considering its relative size and recent growth, which make it worthy of attention; and (2) it's unclear what dictates success for members in the EHMS, and for artists more generally. There is a small but growing body of literature around the relationship between music and local cultural economies. The factors affecting the success or failure of artists in the creative and cultural urban economy should be understood, both from a planning and normative perspective. The EHMS creates a public good and provides cultural and economic services to residents of Portland. The foundation of this public good is dependent on the participants and music makers in this subculture. Understanding what influences their success will, in turn, allow planners and researchers to have a better idea of how to bolster the cultural economy as a public good. Further, understanding how the EHMS integrates with the local culture and economy is generalizable to other subcultures between cities and time periods.

The study is both descriptive and analytical. Descriptions of the EHMS will include empirically examining this subculture and its participants, while the analytical aspect of this paper will examine internal logic, and social and institutional relations that dictate how the EHMS integrates with the local culture and economy. Specifically, the analytical framework adopted in this paper adopts a Bourdieuan analysis of cultural capital (Bourdieu, 1993). While a number of researchers and theorists contribute to my approach, Bourdieu is of particular 
significance, as his research and theory provides a foundation for understanding subcultures through not only a material lens, but also a social and institutional one. The "culture" of this and other subcultures can be thought of as the shared values and/or beliefs that serve to identify or bind a group of individuals together, which in turn influences the articulation of the group's objectives, relating to an individual's or group's economic activity based on shared norms (Ginsburgh and Throsby, 2014). In other words, the culture of a particular group is a public good created by individuals in a group, shared between members, with effects on the immediate urban environment.

The methods used to understand the EHMS include my own observations and research while involved in this particular subculture (as an audience member and occasional performer), primarily by interviewing individuals in the EHMS. In this paper, I give some background context on music in urban environments, largely from the standpoint of culture, subcultures, and cultural production. Subsequently, I examine the previous literature on the relation between cultural products and commercialization. Research questions, based on the literature and preliminary observations, are presented in the research and methods section. They are further explored and examined in the findings and discussion sections. My key findings are: participants are motivated by artistic rather than commercial reasons; Portland audiences are highly receptive to new and experimental forms of culture, allowing them to flourish in a way that would not occur in other cities of 
similar size or urban layout; and the institutional capacity for Portland's artists is significant and well developed, allowing performers to succeed both as artists and as creative professionals.

\section{Chapter 2: Literature Review}

\section{Music in the Urban Environment}

Music is relatively understudied as a geographical phenomenon, despite a number of researchers arguing that it needs to be understood as such in order for geographers to create holistic and accurate pictures of places and spaces (Smith 1994; Leyshon et al. 1995, 1998; Kong 1995). Some of the earliest research on the topic was from a regional geographic framework (Carney, 1978), while more recently there has been a focus on understanding the social, cultural, and economic factors relating to music and its development to specific places (Nash and Carney, 1996). The field of popular music studies has more recently taken on a geographic lens, focusing on local scenes and subcultures, music production, and how the aspects of a certain places influence the rise of certain types of music (Krims, 2002). The overlap between geography and studying music was solidified in the literature by Smith's (1994) paper Soundscape, Leyshon's (1995) The Place of Music, and Kong's (1995) research on music, in which he claimed that "geographers' relative neglect of popular music should not persist" (p. 183). Since these developments, there's been a small but growing 
body of research focusing on the relationship between geography, space, and music, including: Hudson's (1995) work on the relationship between music and urban generation; Cohen's (1995) work on place and urban music; and Kong's (1995) focus on the overlap between cultural politics and music. From these developments, a full length book was formed called The Place of Music (Leyshon et al. 1998), which studied the relationship between music and geography. The focus on music and geography has since taken many forms, from the role of music to social or cultural spaces, place, and identity, to soundscapes and performative aspects of music (Anderson et al., 2005), to the material production and consumption of music (Pinch \& Bijsterveld, 2004). Other studies focus on music as an aspect of the cultural industry, such as Halfacree and Kitchin's (1996) work on popular music in Manchester; Smith's (1997) research on art, industrialism, and the cultural politics of music; Krims $(2000,2002)$ and Mager's (2007) research on rap and hip hop music as it relates to urban geography.

Gibson and Connell's work has been especially useful in understanding music in an urban and geographic context, including their work on writing soundtracks (Connell \& Gibson, 2003), the production of world music (Connell \& Gibson, 2004), the relationship between tourism and music (Gibson \& Connell, 2005), and urban development (Gibson \& Homan, 2004). Geographical studies on music, space, and economics include Power and Hallencreutz's (2002) work on Swedish and Jamaican music, Florida's work on the US record industry 
(Florida and Jackson, 2008; Florida and Mellander, 2008), Watson's (2008) research on the music industry in the United Kingdom, and Sadler's (1997) work on the role of information in the music industry. Leyshon's $(2001 ; 2003)$ more recent work has focused on the study of digital music distribution and the declining sales of physical media like CDs.

\section{Narrowing the focus: Music and Subcultures}

Some musical subcultures are so distinct that their existence and proliferation changed the cultural landscape of a number of cities. Music is an important if not dominating factor in a number of youth subcultures since the 1950s. It has played a critical role in the social movements of the 1960s, and since the 1980s has mediated a number of cultural narratives from the topics of urban decay in punk music to the rural utopianism of country, and everything in between (Hebdige, 1982). Place, in any human-centered sense, is inseparable from culture: Los Angeles has been partially defined by the mythology of Hollywood, New York and Paris by high art and fashion, and a number of cities like Seattle, Liverpool, Manchester, or Berlin would not be recognized as cultural powerhouses without the vibrant music scenes that they house (Currid and Williams 2009; Bell, 1998; Florida, 2002). Areas of cultural consumption might include dive bars that feature local music, electronic dance music (EDM) warehouses, and local radio stations; production points include practice spaces 
or vinyl pressing factories; and, distribution centers might be record stores or DIY online shops that have a local front-facing store.

The proliferation of music production, consumption, and distribution at the local, urban, and global level calls for a rise in critical academic analysis and understanding: one which has yet to adequately form, especially in Portland. It is not clear why music has been an underprivileged area of research in urban studies and planning, but it may be due to the (until recently) supposed non-geographic nature of music, and to the complexity which surrounds musical expression. Some authors have argued that research of enduring cultural products, for example, architecture and visual art, have been privileged over more working-class, popular, and fluid forms of culture, such as music. (Krims, 2012). Studying the EHMS in Portland - and similar subcultures in other cities is valuable because little research has been done to understand how subcultures contribute to the urban cultural economy writ large. More specifically, examining and understanding the EHMS provides opportunities for planners and researchers to understand how artists and institutions interact to create a vibrant, heterogenous cultural economy and community.

The publication of Hebdige's (1979) influential work, Subculture: The Meaning of Style, has drawn the unit of analysis in studying culture to the level of the subculture, especially when the focus of understanding cultural phenomena 
are music or style (i.e., aesthetic qualities). Participation in subcultures have since been, by in large, characterized by the production and consumption of certain types of music and fashion, and taking part in local, and increasingly, online or global music scenes. I would argue that there is an underlying assumption in much research on subcultures that music is the cultural product or centerpiece that binds subcultures together.

Frith (1996) noted that music is essential to youth subcultures, and that it is not "how a particular piece of music or a performance reflects the people, but how it produces them, how it creates an experience... we can only make sense of by taking on both a subjective and a collective identity" (Frith, 1996, 109). In a similar vein, Thomas Cushman (1995) argues that music is "not simply a static cultural object which is produced and consumed, but an active code of resistance and a template which is used for the formation of new forms of individual and collective identity." This notion of resistance here is of particular interest, given the contemporary political climate of leftists and liberals "resisting" various forms of political hegemony of the right. As I will later argue, the EHMS is not actually apolitical, though it may appear so from the outside. There is no explicit politics of, for example, the anarchism associated with punk rock, or the authenticity associated with hip hop. Instead, within the EHMS there is a deeply embedded, even semi-codified politics of resistance to perceived hegemonic or homogenizing forces, whether they be social, cultural, or political. 
To return to the prior research, it's clear some fundamental issues have been teased out by authors up to this point on urban subcultures: musical identity is critical in the creation of subcultures, while the producers and consumers of music in an urban context are often able to identify themselves, at least generally, into one or more subcultures. This latter point has been illustrated by Thornton's (1995) examination of club culture and Hodkinson's (2002) examination of goths.

\section{The Subcultural Economy}

The geographical research that has linked economic development with musical subcultures is nascent, with most work focusing on musical economies: localized areas that illustrate the importance of music industries to urban economies. These analyses themselves are usually framed - at least in theory in the larger context of ideas that draw on work by sociologists who focus on the culture industry.

Frith (1992) notes the different ways that culture has contributed to economies in terms of the proliferation or development of industrial cultural policies, which largely takes three forms: (1) policies that encourage the creation of technology for manufacturing cultural goods for mass market or consumption (such as television), usually geared on the creation of electronic goods and media; (2) policies that focus on tourism, and the attraction of capital that comes 
with this industry, be it through attractions such as museums or music festivals; and (3) somewhat related to tourism policies, are ones which focus on making a city appear more lively and vibrant, culturally, than it might otherwise be of its own accord, with the ultimate goal being to bring in would-be transplants. Hudson (1993) analyzed how music within the culture industry provided local economic regeneration in Derwentside, Britain, throughout the 1980s, while Sadler (1993) demonstrated how Japanese companies invested heavily in the US film industry market to secure areas of investment, research, and development for new technology; there was a cultural component to the Japanese investments, as it spurred frightened outrage from those in the film industry in the US that the Japanese might try to monopolize Hollywood markets. These are just a few studies that briefly highlight the dynamic between culture and the economy, with music being a point of analysis, (or a similar cultural product, such as film).

Within the literature, the cultural sphere is usually situated in a larger creative economy that includes not only artistic and cultural endeavors, but also science, engineering, information technology, and other areas that typically require an educated labor force (Florida, 2002; Hutton, 2009). This well educated labor force often spills over into specific creative industries studio based arts, ceramics, and sound and audio design (Markusen et al., 2008). There is growing recognition among governments, foundations, and investors, that arts bring value, and provide openings for thinking about the roles of artists in art spaces 
and their communities; in other words, national and local interest in new urbanism has been a boon to certain aspects of the cultural economy (Lazzeroni, Bellini, Cortesi, and Loffredo, 2012). This recognition is warranted, as there is data to suggest that artistic spaces attract skilled labor and specialized service jobs in urban economies, and provide attractive amenities for a number of highly skilled and educated businesses and peoples (Florida, 2002; Markusen and Schrock, 2006; Scott, 2000). In a similar vein, Seifert and Stern (2010) examined how community based art - the production and consumption of such art that is rooted in a particular group of people - helps foster community identity and cultural harmony; community art projects indirectly enhance interaction between individuals, generating businesses, jobs, attracting tourists, and increasing networking opportunities. By extension, similar questions ought to be examined for urban subcultures, and will be examined in this study with respect to the EHMS.

Spaces where art and cultural activity exist, including music, can often be informal centers for communities. If they can function democratically, they are run and operated by cultural producers, creating a community's identity or promoting stewardship between residents and stakeholders (Evans, 2002). They can serve to stimulate civic engagement, affecting economic conditions directly and indirectly, and can be crucial for low to moderate income areas that are trying to improve the quality of life and opportunities for local residents: artists and the 
spaces they create are often drawn to these neighborhoods as there exist underutilized assets, opportunity, and potential (Borrup, 2006). These spaces have the potential to function as conduits for creating complex social networks that offer community revitalization, artistic developments, and numerous positive externalities. The multifaceted benefits of art and music spaces in urban areas are dependent on their location, how they are managed and organized, and what type of artistic functions they aim to produce or house. From a market benefit standpoint, the arts and culture economy can provide jobs, help local businesses, and stabilize neighborhoods, in part by offering a kind of place-identity for different neighborhoods connected by arts and culture.

Less theoretically, it's generally thought that local arts and culture economy and generate economic returns and positive externalities by helping neighborhoods capture stronger shares of local expenditures, since residents don't have to travel for arts and culture demands, or decide to spend money on entertainment that's virtual (Bille, 2006). This capital, it's argued, can then re-circulate into the local economy, further developing underutilized land, buildings, and infrastructure that are suitable for the creative economy, but may not be suitable for other sectors. The utilization of otherwise marginal land by investments in the creativity economy should see parallel returns in public and private goods (Bille, 2006). By fostering strong arts and culture in specific places, firms can cluster, leading to strong aggregate economies: sales, income, and 
property taxes should increase, leading to better maintenance and public infrastructure. This, in turn, can lead to cultural business districts that aid in the development of retail and service businesses, such as the Alberta Arts District in Northeast Portland. In the new urban economy, it appears that jobs increasingly follow individuals rather than the other way around, and the development and sustainability of arts and culture hubs are crucial to making cities competitive in the global neoliberal economy.

\section{Beyond the Cultural Economy}

Despite the above research, the academic study of music within urban studies and planning has largely ignored the connections between cultural and commercial aspects of production: examinations of the production of music, community, and identity are often secondary to understanding music within the framework of economic growth, job creation, or what has been dubbed recently in the urban studies and planning literature "the cultural economy" (Gibson and Kong, 2005). The commercial aspects of musical production and consumption has been the subject of only a few studies, which typically orient themselves within the larger framework of understanding the cultural economy as a whole (Caves 2001; Brown et al., 2000). Music is a cultural industry, or a group of economic clusters and networks which is geared at cultural production. The background context of these studies in the academic literature is through the 
framework of neoliberal economics: music is studied in the context of employment and job creation, positive externalities, or through the framework of public policies, and regulatory or institutional settings which promote musical development. While investigating these questions are both practical, and important, they are insufficient in understanding what drives successful cultural production and the creation of cultural products, especially at the individual and community level. Examining this particular subculture through the framework of added economic value would be overly reductive, limiting to the scope of this study, and undermining the intent of understanding the cultural production and output of the EHMS in Portland, Oregon.

An analysis of cultural products cannot take place without an understanding of the cultural consumers, producers, and bystanders in a given urban milieu. Typically, as an individual's disposable income increases, so does their participation in the consumption of goods or services offered by the cultural economy, which is itself subject to competitive pressures which encourage firms to agglomerate together in dense specialized clusters or industrial districts (Scott, 2004). The ways in which various authors have attempted to understand this relation between commercialization and music has been outlined by Negus (1995), often fitting into three broad categories of conceptualization. The first is the idea that commercialization corrupts art, articulated most thoroughly by Adorno and Horkheimer's work, beginning with The Culture Industry, 
Enlightenment as Mass Deception (1944), a concept that would span their work until the 1970s. The second is the notion that commerce is largely irrelevant to the production of art (although art does react and respond to commerce), put forward by Hebdige (1979). Finally, the notion that art and commerce are in constant tension, was thoroughly developed by the sociologist Bourdieu in the late 1980 s and early 1990s. While insights related to the EHMS stand to be gained by both Adorno and Horkheimer, as well as Hebdige's work, I find the final framework put forward by Bourdieu most useful in understanding the relation between the EHMS to the economy and culture of Portland at large. Importantly, Bourdieu's framework provides a foundation for analyzing how social and institutional factors, i.e., social capital and institutional capital, affect the levels of cultural production in a subculture, besides the mere material factors that affect cultural production.

\section{Commerce and Music in Tension: Bourdieu and Cultural Capital}

Bourdieu (1982) dictated the post-Marxist understanding of urban cultural practices as they relate to each other. His concepts of cultural capital, field, and habitus are critical for understanding the social and subcultural norms that create and contextualize cultural products, and his 1982 work, Distinction, provides an empirical outline for studying the development of musical sensibilities in urban environments. In much art, especially many specific subcultures that draw people 
to a certain urban area, the cultural economy is based on an inversion of the fundamental principle of capitalism, or as Bourdieu (1993) writes, "business excludes the pursuit of profit and does not guarantee any sort of correspondence between investments and monetary gains" (p. 39). In other words, for cultural products, as things get more popular or bourgeoisie, they cease to lack the outsider appeal that made them interesting in the first place, despite these "outside" institutions always being dominated by the laws which encompasses it, namely economic and political laws. For example, commercial broadcasters and major record labels often work in a top-down way to homogenize the taste of an otherwise unpredictable public into a stable or predictable culture industry, but this homogenization and commercialization makes these cultural products lack the appeal they initially had for a number of individuals, especially in subcultures. What's more important, from the standpoint of cultural production, is the notion that what matters is the institutions that are a part of the production, creation, dissemination, and consumption of music, (and art). This is a line of reasoning that stems from Danto (1964), to Bourdieu. If researchers are going to understand cultural production, their method of inquiry must:

...extend to all those who contribute to this result, i.e., 'the people who conceive the idea of the work (e.g. composers or playwrights); people who execute it (musicians or actors); people who provide the necessary equipment and material (e.g. musical instrument makers); and people who make up the audience for the work (playgoers, critics, and so on) (Bourdieu, 1993, p. 35). 
For Bourdieu (1993), cultural production is situated in the field defined by what he refers to as relationality. In short, cultural production (and its products) exist within a number of other social realities that constitute objective relations. One of these social realities - though not the only one or even necessarily most determinant one for understanding cultural production - is the quantity of social capital (i.e., recognition) and one's occupation in the fields of cultural production (or the arts). This bleeds into Bourdieu's uncontroversial notion that there are a mix of objective and subjective factors related to the structure of the field. The necessary components of analysis is the current state of a subculture in an urban area, and one's effective agency (i.e., how good one is at networking), in order to gain an accurate picture of a given area of cultural production, in space and time (1993, p. 43).

There are, of course, material factors of power and capital at play in the field of cultural production, in addition to institutional and semiotic factors. Power in the field of culture, as Bourdieu sees it, is heteronomous, or both internal to the institutions of one's cultural field and dictated by external fields that have power over a given cultural field of production $(1993,38)$. For example, one's success as a musical artist is not only dictated by both the internal norms and structures of the genre of music they are in (non-material factors), but the outside (material 
factors), such as whether there are music venues for them to perform in, or independent record stores that can carry their albums.

The diagram Bourdieu uses to represent the location of artistic (i.e., cultural) activity in the broader field of social power and the market is as follows. This diagram can be adopted for the purposes of examining cultural-musical production in Portland, or presumably, any other cultural field in a geographic or virtual space (with limitations).

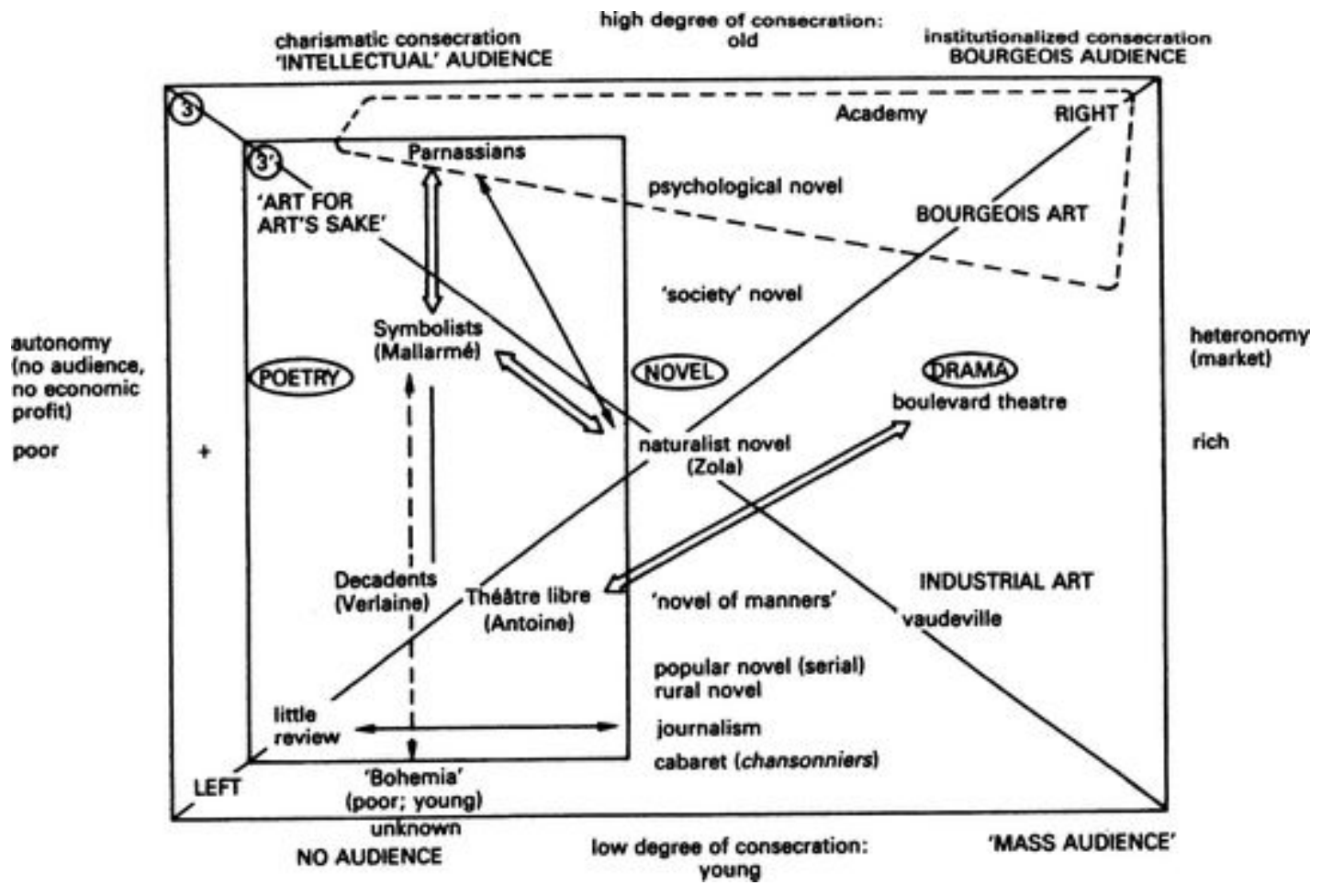

Figure 1 from Bourdieu, 1993: French Literary field in the second half of the 19th century; + = positive pole, implying a dominant position, - = negative pole, implying a dominated position 
The field of cultural production includes the areas of social activity in which authors create a cultural product that is either very fit for consumption on one end of the spectrum (with its ties to market demands and forces), or not particularly easily subsumed into a capitalist system on another end, in which authors experience creative autonomy. These concept maps give us a better idea of what the field of cultural production encompasses: it is an area of social activity in which there are creators who are intent on making a certain kind of cultural product. The form cultural products take is partly to do with a given audience's expectations, values, and demands, similar to other market economies. In other words, the cultural producer, in this schema, never has total control over their work if they are to enter this field of cultural production. Indeed, the extent to which they can be authentic to ideas or artistic forms of expression that they are pursuing might be inversely related to whether or not their product is consumed by the masses, or a niche few. This question is explored empirically by discussing how members in the EHMS pursue the creation of their cultural products.

A cultural product is always created in a web of overlapping social institutions. For Bourdieu (1993), these social institutions were related to galleries, academic journals and newspapers, literary review publications, etc. There are similar institutions involved at work in the examination of musical 
cultural products, but will clearly include spaces such as record stores or music venues, bars, nightclubs, and even virtual realms of consumption like Bandcamp, Soundcloud, or Instagram.. To understand how a cultural producer navigates these overlapping fields it's necessary to understand Bourdieu's (1986) notion of cultural capital, and how it can be used by individuals to gain positions of power through either direct or indirect employment of their social connections .

Cultural capital is tied to specialty fields, and what Bourdieu (1986) calls habitus, or the system of dispositions and tendencies that shape the way individuals perceive the social world around them, and how they react to it, either consciously or non-consciously. Bourdieu (1986) notes that, for example, this kind of capital "explains the unequal scholastic achievement of children originating from different social classes by relating academic success" (1986), and this sort of capital is further divided by Bourdieu into three states: the embodied, objectified, and institutionalized. The embodied state of cultural capital is the sum total of an individual's skills and abilities to create a cultural product. The objectified state of cultural capital is reified by a cultural object, such as a painting or record. These objects have both economic capital, because of their materiality, and symbolic cultural capital, because of their semiotic content. Lastly, institutional cultural capital "is a form of objectification which must be set apart because it confers entirely original properties on the cultural capital which it is presumed to guarantee" (Bourdieu, 1986, p. 47). Institutional recognition here 
is key to this form of cultural capital, as it is in this that "...the form of academic qualifications is one way of neutralizing some of the properties it derives from the fact that, being embodied, it has the same biological limits as its bearer" (Bourdieu, 1986, p. 50).

Institutional cultural capital is a way of formalizing one's qualifications, and serves as a way of reifying the social capital that a cultural producer has. One who has institutionalized cultural capital, in the form of a resident at a gallery or a professor, for example, is less immediately subject to the interplay of forces in the fields of cultural production. Further, this kind of cultural capital "makes it possible to establish conversion rates between cultural capital and economic capital by guaranteeing the monetary value of a given academic capital" (Bourdieu, 1986, p. 51). Institutional cultural capital is more immediately recognized by the labor market, and translatable into an economy of actual capital, and buying and selling of goods, products, or services that these institutionalized individuals may render. In market terms, institutional cultural capital is the most valuable type of capital for one to have in the field of cultural production.

Bourdieu's work provides a lens to frame a number of questions for researchers studying cultural production, and the separation (or lack thereof) between cultural producers and market forces at large. In short, it provides a 
framework to examine how non-material factors affect cultural producers, but is not primarily concerned with how material factors (i.e., market forces) affect them. For this study, I will examine both the non-material factors affecting cultural producers (individual, social, and institutional) through a Bourdieusian framework, and the material factors affecting them, as told by cultural producers themselves.

\section{Chapter 3: Research and Methods}

To understand why and how the EHMS thrives in Portland- how it affects, and is affected by the local culture and economy - I formulated broad research questions informed both by the literature and my own experiences with the subculture.

1. What motivates members of the EHMS to create their cultural products?

2. How do members of the EHMS benefit from their cultural products?

3. How do material factors (e.g., availability of time and space, monetary constraints) affect the cultural production or output of members of the EHMS? What material factors are the most significant?

4. How do non-material factors (e.g., social capital, networking ability, institutional capital) affect the cultural production or output of 
members of the EHMS? What non-material factors are most significant?

5. Do members of the EHMS find Portland to be different than other cities, with respect to this music subculture?

The approach I used to answer these questions was phenomenological and ethnographic, relying on my own experiences and observations and long form, qualitative, semi-structured interviews with 18 participants involved in the EHMS during the summer and fall of 2019. The majority of participants lived in Portland, although some participants had recently moved out of Portland at the time of our interview, or have since moved to different cities. My interviews took roughly 45-90 minutes, and were conducted either face-to-face or by telephone.

I interviewed musicians, sonic artists, gallery owners, operators or curators, music venue owners, record label owners, and employees of local academic and non-profit institutions. Participants are kept confidential, but will be given pseudonyms so that they can be differentiated in the text, in order to aid the reader. Participants ranged from relatively new and up-and-coming artists, to well-established performers with access to a number of major individuals and institutions in this particular cultural milieu. Interview subjects were found through a number of methods, including snowball sampling, intentionally selecting particular subjects, and "cold-calling" through direct messages on social media platforms like Instagram and Facebook. I obtained names and contact 
information from other members of the EHMS that I interviewed, which allowed me to get in touch with members of the EHMS that were more likely to participate in the interview process.

This approach is biased, but this system of referrals allowed me to meet members of the EHMS who were more likely to be more embedded in the subculture, as multiple people would often recommend I reach out to the same individuals. My position as a researcher and someone with experience in the subculture, and especially my familiarity and comfort level with technology and social media provided an outlet to reach out with ease. In this vein, my sample may be biased towards those who have more of a social media presence and responsiveness to "cold calling" compared to those that are less inclined to use social media or technology. For this particular subculture, which is dependent on technology, I would assume that those individuals are few and far between.

I believe that my experiences with this subculture provided a net positive, and in fact were critical in order for me to formulate and answer the research questions I did. However, my proximity to the EHMS, and the theoretical framework I used to generate research questions likely resulted in some threats to the validity of my research, especially interpretation validity (Maxwell, 1996). To mitigate interpretation validity, questions were largely open ended, non-directional and respondents were given as much time as they needed to answer any question(s). Respondents were also asked at the end of every 
interview if there was anything else they wanted to speak out, whether it was related to the interview questions raised or not. My position as a young, White, male-identifying individual also carries a certain aspect of authority when reaching out to individuals for interviews, although the relatively informal nature of my contact might mitigate some of these factors. The fact that my research is investigative, open-ended, and non-commercial, likely made participants more comfortable to talk at length about their experiences in the EHMS. However, I reiterated that if at any point participants were uncomfortable with specific questions, or the direction of the interview more generally, that they were free to not answer any questions, or end the interview entirely. The only difficulty I experienced in getting individuals to speak with me for an interview were logistical issues, such as concern about the length of time an interview would take, or scheduling conflicts.

Through the course of the interview process I asked every participant a number of questions related to the material factors affecting their work, their social and institutional standing, their output as artists, to what extent their cultural production focuses on monetary or commercial success, or artistic success (or art for art's sake), and a number of other largely open ended questions $^{1}$. My interview process changed as I began to understand what questions were more or less effective, i.e., what questions generated a greater

\footnotetext{
${ }^{1}$ Refer to the Interview Protocol section in the Appendix for a full list of questions.
} 
wealth of information. I ceased the interview process upon reaching the point of data saturation, or when it appeared that scant new information or themes would be revealed by talking to more participants (Guest et al., 2006). There was only one "yes or no" question I kept throughout the entire interview process: Do you have enough time or money to make what you want? As my interviews progressed, I began to sense just how much social and especially institutional access dictated the success or failure of EHMS members (from their own point of view). Because of this, I granted more time for questions that focused on social and institutional factors that mediated any given member's level of cultural output, rather than individual factors related to motivation or character traits (Bourdieu, 1993). I asked members of the EHMS about why they live (and stayed) in Portland, what they did for work, and what might be their motivations if they were to move to a different city, and why. After completion of my interviews, I analyzed transcripts while coding responses by themes related to the aforementioned subtopics of individual, social, and institutional aspects of the subculture, and economic vs. artistic motivations of those involved in the EHMS ${ }^{2}$. During this time period, I also attended a number of shows and performances associated with members of the EHMS, as well as other artistic spaces and institutions that participants mentioned in interviews, such as S1, Beacon Sound, Holocene, and various house venues. This information was processed

\footnotetext{
${ }^{2}$ Refer to Appendix for full list of thematic codes used.
} 
quantitatively and qualitatively. I recorded approximate frequency of performances, number of audience members, and costs of attendance. For the latter, I noted the geographic location of venues, the type of space these performances took place in (i.e., house, professional venue, etc), and noted recurring or familiar performers and attendees.

\section{Chapter 4: Findings and Discussion}

\section{Summary of Findings}

My interviews with participants in the EHMS produced three broad findings: (1) participants were motivated (especially in the genesis of their careers) primarily by artistic, rather than economic or commercial, reasons; (2) the openness and receptiveness of Portland audiences allows for artists, and more specifically, experimental electronic musicians, an opportunity to perform in a way that is qualitatively different than other places. The size of Portland as a sort of "middle ground" between a small and large urban area allowed participants to network in a way that they thought would be more effective than somewhere like New York City or Los Angeles. However, Portland is still large enough to offer a number of venues and performance opportunities, with this relationship mediated in previously unexamined way by social media technology; (3) perhaps most importantly, the institutional opportunities, connections, and infrastructure in Portland was absolutely critical to the members of the EHMS for 
them to book shows, release records and sell merchandise, learn and teach others, and network beyond Portland. The majority of participants noted that they would not be able to be successful, especially not to the degree they are or hope to be, without these institutions.

\section{Art for Art's Sake and the Non-material motivations of Participants}

Out of every participant I interviewed, not one mentioned that they were primarily motivated by economic or commercial reasons, i.e., potentially making money from their music, although all of them expressed sentiments that it would be a nice "added bonus". Some participants did express hesitancy to perform without being properly compensated. This is not to say that participants thought they shouldn't be paid for their cultural products, in fact the opposite sentiment was often expressed. However, given that their cultural product is music, in a relatively niche and experimental subculture, none of them expected much monetary success. As one artist mentioned "It's experimental music. No one gets in this for the money. You have artists like Tim Hecker ${ }^{3}$ or Daniel Lopatin ${ }^{4}$, but other than that, no one is doing this because they think they are going to make it big."

The occupations of many artists interviewed aligned with this sentiment, as there were strong demarcations between their jobs and the pursuit of their

\footnotetext{
${ }^{3}$ Tim Hecker Biography. (n.d.). Retrieved from http://www.kranky.net/artists/heckert.html.

${ }^{4}$ Brooklyn's Noise Scene Catches Up to Oneohtrix Point Never. (n.d.). Retrieved from

http://www.villagevoice.com/music/brooklyns-noise-scene-catches-up-to-oneohtrix-point-never-6393906.
} 
music. Some had jobs unrelated to their music production, noting that the distinction between their work and their music allowed more creative freedom for the latter. Of the participants I spoke to, ten were full time artists, and eight were part time artists, having either part time or full time jobs in addition to being involved in the EHMS in some capacity or another. Full time artists earned a living through touring, songwriting and music production, and teaching in areas related to their music. Among the part-time artists, four worked in education, two in creative fields (like graphic design or installation work), and two in the service and retail industry. Because I tried to seek some of the more prolific members of the EHMS for my research, it's likely that my sample, while not representative in general, also represents full-time artists to a greater degree than one might expect. From my own general experience with the EHMS, I can firmly say that most members are not full time artists, and instead pursue their art form in their spare time, in addition to their full or part time job. Even members I interviewed that might be conceived of as part of a "creative class", e.g., members who had jobs as graphic designers, music teachers, etc., noted the need for boundaries between their work and their music. In other words, all participants spoke to a distinction between their artistic pursuits - mediated by one's personal creative capacity and self-determination - and their jobs or the "managed creativity" they might experience in an occupation that has a marginal relation to their music or craft. This sentiment of managed creativity was especially present when I asked 
one participant, Fernow, a graphic designer, about the relation between their job and their music. Fernow is white, in his mid-20s, is well educated and has a clean cut, almost business-like demeanor, at odds from the experimental and electronic noise music he produces:

There's an inadvertent relationship. When I started doing design, I thought that what I wanted to do all the time, and totally immerse myself in this 'creative' pursuit. Then, I realized that design isn't a part of my life, it's just another job. It's not a culture or an identity: it's the same as being a house painter or a barista, which l've both worked as. The 'culture' behind design is actually kind of repulsive to me now. Now I realize I rather just separate my art from my work.

For all participants interviewed, there was an aspect of autonomy that revealed itself through the pursuit of their art, and the pursuit of cultural production that is not commercially viable. These aspects of autonomy were further enhanced by the institutional capacities of Portland, and the network of social support systems that the EHMS created and participated in. Many participants mentioned that they did not have stable or "traditional" forms of employment, instead having a mix of jobs or "portfolio careers," in which they worked at a number of temporary jobs, or worked part time. The dynamic nature of participants' occupations or careers was aided by their generally flexible skillset, bolstered by their experience and participation in the EHMS. All participants had a level of comfort and familiarity for jobs that required technological know-how and creativity, and a number of participants in the EHMS 
supplemented their income in ways that reflect this, such as music production, audio visual and stage tech, and graphic design. This supplementation of income that artists are capable of has sometimes been dubbed the "commodification of culture" (Frank, 1998; Scott, 2000). Taking an even more critical position, Lachmann (1988) referred to this as "an appropriation of subcultural artifacts from their communities for sale to the general public" (p. 232). Participants, however, generally regarded this "appropriation" as more of a co-benefit of their involvement and dedication to their cultural production. Participants were quite excited about the possibility that the EHMS, and the cultural products that stem from it, might become more accessible to larger audiences. I asked one participant, Basil, who has been involved with the EHMS for at least five years, if they thought the scene could grow and become more accessible as a general cultural phenomenon of Portland (and not just New York or Los Angeles). They stated:

It's actually very exciting. We are starting to get bigger spaces and larger, more diverse crowds that aren't familiar with this kind of work. The scene is going to get bigger. Things like Ambient Church $^{5}$ are happening now. It sold 600 tickets for one night. The influence of technology, and how much people want technology involved in their experiences all the time gives us more opportunity. We know how to create projections, sound fields, and video art, and people are

\footnotetext{
${ }^{5}$ Carroll-Allan, J. (2018, November 15). Ambient Church Attempts to Create Religious Experiences by Taking Concerts Out of Bars. Retrieved from

https://www.wweek.com/music/2018/11/15/ambient-church-attempts-to-create-religious-experiences-by-taking-concerts-o ut-of-bars/.
} 
demanding these things more and more. So many people I know are now involved at Disjecta, PICA, PNCA, Open Signal, Friends of Noise and other spots.

In short, it's clear that while members of the EHMS are not motivated primarily by financial or material concerns, the increased market demand of new, electronic, and experimental forms of music and listening experiences can provide career opportunities for a number of members. Of the participants I interviewed all had generated income from their work, and six participants primary source of income came from combinations of performing, teaching, and selling physical products like merchandise, CDs, vinyl records, etc. Participants motivation for making music varied greatly, but most answered in ways that were culturally embedded, non-economic, and stressed themes of the local and greater artistic community and communication. One participant I spoke to about this, William, an electronic artist in their late 20 s with a body of work that has already spanned seven years, noted that it would be "nice" to make money from their music, but it wasn't their focus:

I haven't been willing or able to align my personal ideas and impetus for making music with a strictly commercial market. I make experiential music, that requires active participation, be it mental or physical. Quite a niche at this time. It's not that I am against commercial music or its proponents though. I am simply skeptical and wary of being too deterministic with my practice. Much of the commercial work that I hear these days has a motive of commerce. If commerce is the main reason for music making, it's as though I were to cut down a tree and 
whittle it down to a toothpick, making waste of all other options the wood presented me with.

Others participants had motivations which were concerned with rebuking the status quo or dominant narratives through an artform that is often viewed as challenging, outsider, or explicitly hostile to "easy listening" experiences. Alyn, a musician and teacher in her early $30 \mathrm{~s}$, is a participant whose music trajectory began through learning fairly structured and classical music paradigms, focusing on piano and guitar. Her work still incorporates acoustic elements, but now in a way that might be totally unrecognizable if they weren't visible on stage. The sonic qualities of her music, while often comforting, might also be described as alien, magical, and difficult. She spoke personally of their motivations against a sort of "easy listening" consumer culture:

As a society we are stuck into ruts where we have these strange agreements, in finance, in capitalistic values, in how we understand our environment. We listen to music in $4 / 4$, that's in greek tuning, in square rooms, all facing one direction. We structure and compartmentalize, and that's reflected in most of our music. If I can make music that isn't like that, it might open people up to thinking about other things differently too.

In summary, the motivations between members of the EHMS for pursuing music vary, but involve self-sustainability, community, expression, and countering both market and aesthetic homogenization. Instead of focusing on monetary gain, members of the EHMS are interested in trust-based and non-financial 
exchanges of time, equipment, social know-how and networking, and technological education. The people in the EHMS are involved in mutual, culturally-productive labor because of the art itself, not any material gains it might incidentally generate. Respondents often spoke to the idea that for themselves, and others that they know that were heavily involved in the EHMS, individual and collective success implied each other, and their cultural production was far from a zero-sum game. Categorical distinctions regarding motivations and dimensions of success are useful here, not only for the EHMS, but similar subcultures focused on cultural production. Participants that were less experienced in the creation of their art and music were generally more motivated by artistic rather than commercial factors, but as they became more well versed in their craft, either incidentally or explicitly became interested in monetizing (or at least the ability to monetize), their cultural products.

The value of the kind of cultural production created by members of the EHMS has not been well examined in the literature, which instead typically focuses on quantifiable labor or products that is explicitly tied to some sort of existing market. Indeed, if measured the commodity share produced by the EHMS would be small compared to a number of other cultural-production economies that characterize the Portland area, more often known for "brews and bikes" than its music scenes, but this may not always be the case (Heying, 2010). The subculture of the EHMS is also quite porous as a culturally productive 
scene, with members involved in art institutions, galleries, dance venues, educational outlets, and technology and programming workshops, all as a result of their music.

The cultural production of the EHMS could, in theory, be measured and compared with similar markets of cultural production, but the sum value of the artistic labor produced by the EHMS is in part intangible and independent from formal market exchange or price indexes of social value. Still, the cultural production of the EHMS adds a unique and significant contribution to the welfare and creative commons of Portland, not just for members of the EHMS themselves, but the number of individuals, communities, and institutions connected to the EHMS through the myriad ways that it "expresses" itself. This is reflected by the generally non-material motivations of participants, which I would further break down into three main categories: aesthetic, political, and technical. Participants motivated by aesthetics fall into the "art for art's sake" category, primarily motivated by self-expression and self-actualization through their artistic products. Other participants, while interested in art for art's sake, placed more emphasis on being able to "communicate" through their art, albeit abstractly. These participants also often spoke of their desire for their art to impact audiences in a social or political way, similar to how Alyn spoke of her desire to make art that challenged audiences' conceptions of "capitalistic values". Finally, some participants spoke of their technological motivations, i.e., wanting to hone 
and perfect the craft of playing their instrument, or mastering any number of technical apparatuses required for making their music, such as synthesizers or programming environments. These participants also spoke to the "marketability" of learning the ins-and-outs of these technical apparatuses, as these skilled transferred into audio and visual technology jobs, programming careers, and educational prospects.

\section{Portland's Affordability and Openness for Artists}

The housing and market landscape in Portland has changed rapidly since the Great Recession, with an influx of "outside" capital, a number of investments from tech firms from the Bay Area and other technology hubs throughout the country. Still, the city has a history of relative affordability among large cities on the West Coast of the United States. This affordability and relative surplus of housing stock has long lent itself to a number of DIY scenes and musical subcultures ranging from punk, to jazz, hip-hop, techno, and especially noise music (London, 2017). Artists could generally work retail or service jobs while pursuing their art. A number of participants noted that they moved to Portland in part due to the affordability of housing and the cost of living. The surplus of housing in Portland relative to cities like Los Angeles, New York, San Francisco, or even Seattle creates a unique situation for music and musical performers: musical consumption doesn't have to take place in venues that operate strictly for profit. 
Previous research by Currid (2007) and Markusen and Schrock (2006) has shown that the high cost of living in cities such as New York can stymie the initial development of communities of artists and musicians. This has significant consequences for the creative economy, especially as it relates to the production and consumption of music. Private venues cannot take chances on art or music that is otherwise "outside" mass or mid-market consumability. While Portland venues like Wonder Ballroom or the Rose Theatre occasionally allow for niche or experimental artists with a strong local or national following to perform, these venues are rarely "friendly" to musicians in the EHMS. However, a number of house venues, (such as Ivon House, Body Flesh Pink World, Blood House, etc.), essentially allow for artists to perform and get their foot in the door, creating a local following and developing a level of professionalism before they transition into more established or even professional, and internationally recognized venues in the Portland area, such as S1, or PICA. Of course, the sheer availability of housing isn't enough. As one performer from Modesto, California with over 10 years of experience playing live venues and booking tours remarked:

There's plenty of places people can play in Modesto... there's a lot of huge houses that would be great for bands or performers but there just isn't anything going on there. I really don't know why. Maybe there isn't enough young people or maybe people are afraid of having these big pretty suburban homes used as makeshift venues for bands. 
It is traditionally understood in planning and economic development that the clustering of similar firms, labor supplies, resources, and varying institutions is critical to the efficiency of local economies, creating beneficial agglomeration economies, and this is also the case with the cultural economy. The availability of space, that is, a specific type of space where performers can become prolific cultural producers is necessary but insufficient for a thriving cultural economy. For members of the EHMS, and many other creative subcultures, the availability of housing stock and relatively cheap space provides the (literal) foundation for a community of experimental musicians and makers to gather together to practice, perform, and hone their craft, creating a kind of feedback loop (Zukin, 1982). Some research has examined how artists seek out communities to share not only physical materials or information, but solidarity and community itself (Lloyd, 2010). The availability of space allows people to experiment creatively (both artistically and in terms of businesses), leading to shows and performances which are more experimental (and sometimes amateurish) than larger cities, with audience expectations adjusting to match this unique cultural milieu. What is unique about the EHMS is that most members mentioned their comfort with playing at varying types of places and spaces. The relative abundance of house venues in Portland - that is, the abundance of single-family housing stock that lends itself well to performances - allows members to play early and often in their development as artists, as many only need a PA, minimal gear, and usually 
perform by themselves. The experimentation and relative openness of the community of the EHMS does not discourage "sitting" shows, performances that are niche, or that have limited audiences: artists I spoke to were often equally as excited about performing in intimate, free of charge venues as they were about performing at arts festivals at local institutions. Thus, what sets the EHMS apart from other subcultures in this respect is the relative ease and adaptability of playing at small and intimate venues, such as house shows, but also the ability of many artists and performers to scale up their work into a number of professional and creative outlets and performance spaces, such as music festivals, or large scale installation work at places like Disjecta, PICA, or the Portland Art Museum.

Participants that I interviewed who had toured a number of large cities in the United States and abroad (typically Europe), noted a qualitative difference between Portland's audiences and other cities: a certain level of acceptance for new, challenging, and even unpolished work that they did not experience anywhere else. The majority of participants noted this about Portland audiences and cultural consumers compared to other cities, though there was divergence of opinion when I asked participants what they thought the reasons for this openness might be. Some members did mention that this difference exists because of the relative plethora of spaces that artists can perform at that shy away from being polished, professional and for profit venues. Others noted that it had to do with how tight-knit the EHMS community itself was. One member of the 
EHMS, Kerns, a thirty one year old performer who tours locally and internationally - a somewhat common occurrence for members of the EHMS discussed what seemed to her to be a unique sense of openness and solidarity for artists in Portland:

I'm always excited when other people are successful. Everyone's really supportive. I love helping people break into the scene. I can't offer a lot of money, [but] if I can find a new artist that no one has ever heard and book a show for them and it will be a successful show or the biggest show they've gotten to play, it's exciting to be able to offer that.

The sentiment expressed in the above quote is indicative of the importance of the sense of community of cultural producers noted by a number of researchers on the subject (Becker, 1982; Perl, 2005; Lloyd, 2006; Currid, 2007). The overwhelming majority of participants mentioned that they could not be successful, artistically or economically, without the unique community of the EHMS. As a whole the EHMS has the social qualities of both openness to new and outsider art, and willingness of participants to help others, a rare combination in the art world. For members of the EHMS, openness and acceptance expresses itself in ways that diverge from other subcultures. Performances are often calmer than most music shows, audience members are often exceedingly quiet, only use their phones if recording or documenting the performance, and are often seated, or at the very least, not moving around much. As one participant mentioned, "If I'm playing, and everyone's eyes are closed... I know I 
got something there, I'm kind of on the mark. If people are shuffling around in their seats, l'm probably doing something wrong."

Only one participant said they "could be" successful without access to others and the institutions in Portland, but noted that they "weren't sure how it would look or take place" and that it would "take a lot more work". For some participants, this sense of community entailed providing material opportunities for those that lacked them, offering physical equipment like public address systems for sets, or allowing performers to book venues and play shows in their homes. For more seasoned members of the EHMS, this might mean acting as a conduit to key institutions or companies, such as private record labels or local radio stations. One participant from Pittsburgh, comparable to Portland both in terms of urban geography and various music scenes, such as experimental and noise music, echoed similar sentiments:

Artists are prone to help each other, I do feel like a rising tide lifts all boats... the experimental, noise and ambient circuit is pretty big in Pittsburgh, as far as experimental music can be. You see the same people everywhere because of how small Pittsburgh is, and the scene is so supportive. I'm constantly being asked about billing and booking and vice versa. I think smaller cities are the places that people in these scenes are going. New York and LA aren't affordable, you just can't live there anymore. People are going to places like Akron, Dayton, Cleveland, Pittsburgh, Portland, and Baltimore.

The importance of a like-minded, supportive cultural community for cultural production has been noted by Becker (1982) and Perl (2005). Similar findings 
have been demonstrated by research on the social networks of "maker-movements", especially "micro-makers" which contribute to the cultural economies of urban areas (Davies, 2017; Wolf-Powers et al., 2017). More recently, Lloyd (2019) looked at the importance of the artistic community in his study of Chicago's bohemian neighborhood, while Currid (2007) noted how critical it was that artists saw themselves as embedded performers in a network of individuals that were receptive and open to their art. What sets Portland apart from many (but not all) cities in the cultural economy is that it has enough social, institutional, and physical structures for individuals to take advantage of, while still being relatively affordable for artists. One interviewee, Brynda, a multi-instrumentalist and composer who was cautiously deciding to move out of Portland remarked:

The cost of living is low enough that I can actually live here and make a living as an artist and not have to spend all my time working for some tech company. I wouldn't have time to make music [doing that]. When I go to cities that are more expensive, I feel like their art scenes suffer. Everyone is working full time, and they can't make art. You just can't be dedicated if you are spending all your time at a job.

The majority of participants echoed the above sentiment. All participants were asked if they had enough time and/or money to pursue their art or music. The majority of participants said that they did not have enough money to pursue their art in the capacity that they would like to. A minority of participants remarked that 
they did have enough money, but this was often due to the very minimal costs of their musical set up (for example, nothing more than a laptop and a set of studio monitors, which in total can be cheaper than $\$ 2000$ ). One participant noted how all of their work can be created through "simple software that is open source, and boasts a community of like-minded makers". It's important to note however that no participants said they have as much time as they wanted to pursue their art, even among participants who were involved in electronic music at a professional level. Participants generally did not state that, because they only have a limited amount of time to create their art, their art suffers with respect to quality. Instead they spoke of the diminished output of their work, which of course, could indirectly affect quality. One participant mentioned that they knew they could not pursue their previous career, which required forty hours of work a week that was unrelated to their music, and pursue their craft. Instead, they spoke of their ability - and the ability of others that they knew - to work forty hours a week or more for some period of time, before quitting, securing a part time job, and using the savings they secured in previous positions to live relatively comfortably for a period of time. A number of participants actually spoke to the idea of enjoying totally separating their work, i.e., what they get paid to do, from their art, as this allowed for more artistic freedom. Participants were well aware of the risk involved in taking this route, especially without material or social safety nets like healthcare. With respect to the needs for physical (e.g., studio) space for artists 
to practice and perform in, participants were generally split. About half of the participants said that they needed more space, or at least a dedicated space, to pursue and perform. As one participant said, "I have enough time. I sort of have enough money, but what I really don't have is the space".

\section{From Community to Institutions: Portland's Institutional Capacity for the EHMS}

Typically, as participants involvement in the EHMS became more involved, their requirements for physical space and social and institutional connections increased. The participant quoted directly above initially moved to Portland because of its vibrant experimental and noise music scene, which they discovered through the documentary People Who Do Noise, ${ }^{6}$ and spent a number of years in Portland as an experimental musician before Portland Community College (PCC) started its Music \& Sonic Arts Program, with programs of its kind not typically offered at community colleges. Participants were often directly involved in a number of public, private, and non-profit institutions which were critical for their cultural production, and perhaps more importantly, necessary if they wanted to further their development as professional artists, musicians, and makers. Table 1 below breaks down this typography.

\section{Table 1}

Institutions and Organizations connected to the EHMS

\footnotetext{
${ }^{6}$ People Who Do Noise (n.d.). Retrieved from http://www.peoplewhodonoise.com/
} 


\begin{tabular}{|c|c|c|c|}
\hline Institution & Function & EHMS Function & Location \\
\hline Portland Community College & Public College & $\begin{array}{l}\text { Education, Hardware, } \\
\text { Networking }\end{array}$ & Multiple \\
\hline S1 & Events; Workshops & $\begin{array}{l}\text { Music Venue; Workshops; } \\
\text { Education; Networking; } \\
\text { Hardware }\end{array}$ & SE Portland \\
\hline Creative Music Guild & Events & $\begin{array}{l}\text { Education, Performance, } \\
\text { Networking }\end{array}$ & NE Portland \\
\hline Turn, Turn, Turn & & Performance & NE Portland \\
\hline X-Ray & Radio Station & Airtime & N Portland \\
\hline Freeform Portland & Radio Station & Airtime & N Portland \\
\hline Pacific Northwest College of Art & Private College & $\begin{array}{l}\text { Education, Hardware, } \\
\text { Networking }\end{array}$ & NW Portland \\
\hline Open Signal & Media & $\begin{array}{l}\text { Education, Hardware, } \\
\text { Networking }\end{array}$ & NE Portland \\
\hline Portland State University & Public College & Education, Networking & SW Portland \\
\hline XChurch & Events & Hardware, Performance & NE Portland \\
\hline Holocene & Events & Music Venue & SE Portland \\
\hline Ivon House & Events & Music Venue & SE Portland \\
\hline Boathouse Microcinema & Events & Music Venue & N Portland \\
\hline Leaven Community & Events & Music Venue & NE Portland \\
\hline Killingsworth Dynasty & Events & Music Venue & NE Portland \\
\hline Liquor Store & Events & Music Venue & SE Portland \\
\hline Odyssey & Events & Music Venue & N Portland \\
\hline Ace Hotel & Events & Music Venue & SW Portland \\
\hline $\begin{array}{l}\text { Portland Institute of } \\
\text { Contemporary Art }\end{array}$ & Contemporary Art Center & Networking, Performance & NE Portland \\
\hline Disjecta & Contemporary Art Center & Performance & N Portland \\
\hline Specs Records & Record Store & Record Store & N Portland \\
\hline Little Axe Records & Record Store & Record Store & NE Portland \\
\hline Musique Plastique & Record Store & Record Store & NE Portland \\
\hline Beacon Sound & Record Store & Record Store; Music Venue & NE Portland \\
\hline Control Voltage & Merchandise & Workshops & NE Portland \\
\hline
\end{tabular}


One participant, Kent, who has had a varied and lengthy career in Portland as a sound artist, musician, gallery artist, and educator summarized various institutions' roles in the EHMS, noting that:

PICA was foundational to a ton of experimental and performative art, and made space and aggressively looked at sonic art in contemporary culture, and its role. They have a creative exchange lab and precipice fund grants for younger artists to get lower level grants. The Regional Arts and Culture Council has grants open to sound, and The Oregon Arts Commission offers things as well. Friends of Noise is also a unique organization that's focused on youth based music and sound design that exists at a scale that's just not in any other city.

Kent's role in education allowed him to speak more to institutions in the EHMS that provide funding and educational resources for artists. It is difficult to argue that one kind of function that is provided by various institutions is more important than another, but it is clear from talking to participants that spaces to actually perform, and areas to network and bolster social connections are critical for the cultural products of the EHMS to actually be consumed. As mentioned, the large number of potential spaces to perform, especially for novice and intermediate performers, puts Portland in a unique position compared to larger metropolitan areas like Los Angeles or New York. Because of the informal and fluid way that shows are booked for EHMS members - often requiring social references or recognition - networking is also critical. Some participants in the EHMS are relatively well known within urban electronic subcultures at the national or 
international level, and so the functions of networking is no longer as valuable to them compared to nascent artists, however, Portland also has a number of record stores that are remarkably open to carrying local and otherwise niche CDs and records. As one member mentioned:

Little Axe records is great... Musique Plastique, and Green Noise Records before they closed down... any of those places I could come in and talk to the owner and leave some merch with them, and if it sold we could work out the shares. Having physical copies of your stuff out their boosts you a bit, both in terms of recognition and with some extra money.

Airtime provided by local radio stations Xray.fm and Freeform Portland provided complimentary functions to performance spaces and distribution of physical merch by local record stores. Both stations have frequently featured music of members in the EHMS, and members of the EHMS often volunteer their time to both stations as volunteers. Both stations regularly promoted shows and performances of EHMS members as well.

Recognizing the social and institutional foundations of cultural production is necessary in understanding urban cultural production, whether it is related to art, music, or crafts. Institutions operate in urban environments not as atomized units, but embedded into a system of relations that help or hinder cultural production (DiMaggio and Powell 1991; Nelson 1994; North 1990). The institutions listed above do more than just provide cultural amenities in a general sense for members of the EHMS, and the greater Portland public at large: they 
provide the necessary tools for individuals to create cultural products, not just consume them. Individual participants are limited in terms of knowledge, resources, and the processes that are required for music making, or cultural production more generally, but communities and institutions mitigate these limitations, and allow individuals to overcome them (Doussard et al., 2017). Coordination of members in the EHMS is also dependent on the institutions that exist in Portland, and the norms and routines that these institutions have in place (either organically or explicitly) (Veblen, 2017).

The community aspect to which participants referred occurs in particular institutions that support both the EHMS as a subculture, and the cultural economy of Portland more generally. Participants noted the differences between the EHMS and other scenes, but also spoke to the overlap of the EHMS with a number of other industries of cultural production - audio visual technology, visual art, gallery work and installations, workshop and maker spaces, to name just a few - by way of the institutions that members of the EHMS were involved in or connected with. Because of both the experimental and electronic nature of performances of the EHMS, the connection of members to institutions is more prevalent than other music subcultures (e.g., punk or hip-hop). While no participants that I interviewed had occupational background in technology prior to or during their involvement in the EHMS (such as programming or software development), the high concentration of tech firms in the area might make 
Portland audiences more comfortable with art and music that is technologically focused. The technological aspects of the EHMS allow for opportunities for participants to code in software such as $\operatorname{Max}^{7}$ (often needed for live performances), focus on audio-visual installations, or put on performances in galleries. As one participant noted:

I perform pretty much anywhere really. I favor static spaces. Galleries are good, as they have a strong cultural context and background rules. Public spaces are really great too, as people are naturally curious and want to experience the work, generally. Institutions and project spaces are also a go.

The high concentration of prominent institutions throughout Portland are clearly a major reason that the EHMS and the cultural output of its members exist as such, and have been able to move from performing at the plethora of house and DIY-oriented venues to more professional outlets like Disjecta or PICA.

\section{Key Institutions}

$\underline{\text { s1 }}$

$\mathrm{S} 1$ is a 501 (c)3 non-profit, artist-run project space and contemporary art center. Funding primarily comes from membership dues and donations. Its mission is to present visual art, performance and education programming that is critical, responsive and accessible. They aim to do this through low-cost workshops, events and exhibitions, providing resources for a community of artists

\footnotetext{
${ }^{7}$ Cycling '74. (n.d.). Retrieved from https://cycling74.com/.
} 
who support each other in their experimentation. S1 began in 2014, initially started by Felisha Ledesma, Alex lan Smith, and Erik Carlson. Ledesma, Smith and other core members, including Alyssa Beers and Alissa DeRubeis, aid in programming and design. Smith, a graduate of the Pacific Northwest College of Art, teamed up with Ledesma after they both expressed an interest in making a space for art that was underrepresented in the community. In 2017 S1 relocated from the Hollywood District of Portland to NE Sandy Blvd. When asked about the importance of various institutions in Portland, every participant mentioned S1. In 2014, I was largely unaware of the growing electronic music scene in Portland, until someone invited me to a show put on by $\mathrm{S} 1$. Before this time, the electronic music I had consumed in Portland was either at dance venues like Holocene or the Liquor Store, or small and intimate house shows. S1 was originally located in a large underground space below a parking lot, with a capacity large enough to effectively allow for conceivably anyone interested in electronic music in Portland to gather at one place, all at once, which was then (and now) unprecedented. The set up was simple, and reminiscent of rave venues in cities with a more established or "traditional" history of electronic music consumption like, London, Berlin, or Detroit. Consumers and participants of events and shows put on by 1 at this time typically had close connections with the Pacific Northwest College of Art (PNCA), as the students of that college generally found themselves in a cultural milieu that was already consuming experimental art, and music that 
either explicitly or accidentally distanced itself from other scenes in Portland, such as punk, metal, or folk.

One participant I interviewed stated:

S1 was really a turning point for me. I had just moved to Portland, and had very little experience with the scene. Someone invited me to an event at S1 and I was

like, 'OK, there's legit art happening here', and that was around 2014.

After S1 moved in 2017, the non-profit began to focus more on workshops and curated events rather than live shows, largely due to a change in Portland's fire code, which limited a 250 square foot area to 50 occupants. ${ }^{8}$ To date, there is no venue in the Portland area hosting electronic music shows with the same frequency and capacity as the original S1. Volunteers at S1 suspected that the change to Portland's fire code was partly in response to the Ghost Ship Warehouse Fire in Oakland ${ }^{9}$ which resulted in the deaths of 36 people in $2016 .^{10}$ A volunteer at S1 described how damaging this change in Portland's fire code was to the non-profit as a music venue:

We used to be able to have around 180 people, and then the occupancy and building law changed regarding sprinkler systems. We made most of our rent, at least half, through shows, and when you can only have 49 people... we just

\footnotetext{
${ }^{8}$ Life Safety/Building Code. (2009, January 20). Retrieved from https://www.portlandoregon.gov/bds/article/226787.

${ }^{9}$ Sulek, J. P., \& Gafni, M. (2016, December 15). The last hours of Oakland's Ghost Ship warehouse. Retrieved from https://www.eastbaytimes.com/2016/12/11/oakland-fire-ghost-ship-last-hours/.
}

\footnotetext{
${ }^{10}$ Author note: Though this event occurred before my study started, I recall various sentiments expressed by artists and performers in Portland. At the time, I was living in an eclectic household of musicians and performers who knew individuals that were at the fire when it happened. While sentiments expressed were, as expected, full of melancholy and disbelief, the more common and visceral sentiment was outrage. Performers and event planners were frustrated at the careless and preventable loss of human life, and there were concerns that - as has happened in the past - dance and rave events would be generally demonized. Members of the EHMS that I spoke with thought the event was due to the irresponsible actions of an individual that effectively operated as a slumlord.
} 
couldn't afford our rent, and we were thrust into a very difficult model to stay operating. We are $100 \%$ volunteer run, so we don't have the extra time or staff for more workshops. It takes so many more events now to make up for the money that one large dance party could have, and it's really taxing on our community. This model of running only through volunteers is also unequitable, because people who can't afford to volunteer their time don't get a say in what happens.

$\mathrm{S} 1$ is a unique space, as it allows individuals with limited professional experience the opportunity to play and perform in a way that allows national and international recognition. One participant noted that "If I'm trying to get booked in Europe... and venue owners or operators see 'S1' on my performance history, they know that counts for something, and there aren't very many places like that in Portland". S1 also operates the Synth Library, the only of its kind in the United States. The Synth Library was created in Spring 2016 in partnership with 4MS Company. 4MS started as an effect pedal business in Chicago in 1996, before relocating to Austin in 2002. The company shifted from making effect pedals and guitar accessories in 2009 , focusing on synthesizers and eurorack modules ${ }^{11}$, and finally settled in Portland in 2012. It is a unique resource at S1 for hands-on access to eurorack synthesizers, modular synthesizers, DJ gear, recording equipment and other electronic music instruments for people of all experience levels. Regular introductory courses are offered to get started, and facilitated

\footnotetext{
${ }^{11}$ Groves, W. (2019, April 11). Intro to Eurorack Part I: Doepfer's Beginnings and Power Supply Basics. Retrieved from https://reverb.com/news/intro-to-eurorack-part-l-doepfers-beginnings-and-power-supply-basics.
} 
working hours for exploration and experimentation are available four to five days of the week at its onsite locations. The library has been incredibly successful, receiving donations from a number of synth companies, and hosting weekly workshops and events since its inception. Synthesis is a relatively technical component of musicianship, with the barrier to entry primarily revolving around the cost of hardware, which the Synth Library ameliorates for anyone interested in the EHMS in Portland. The Synth Library has been so successful that electronic music institutions throughout the world often contact the non-profit to learn how to set up their own synth library. This best example of this is S1's sister site in Prague, run by Zvuk, an open media lab with connections to the Goethe Institute. ${ }^{12}$ Hardware donations for the synth library in Portland and Prague are secured by volunteers in Portland, while Zvuk secured physical space for the synth library in Prague. Zvuk and S1 received a grant from the United States Embassy for Women's Development for start-up and labor costs. Today, S1 continues to play a major role in the EHMS as a site for music, workshops, visual and sonic art consumption, and community gatherings.

\section{Portland Community College}

Portland Community College (PCC) offers a Music and Sonic Arts Program at its campus in NE Portland. Established in 2014, it is one of the few of its kind offered at a community college in the United States. The aim of the

${ }^{12}$ Kurzy a události. (n.d.). Retrieved from http://www.zvukpraha.cz/synthlibraryprague. 
program is to focus on contemporary and commercial music, and explore the limits of what is technologically and artistically possible through the creation of "new sounds, new instruments, and new methods of performance and composition". ${ }^{13}$ The program combines music, art, science, coding and design and focuses on outlets that allows students to develop professional skills for the arts, education, technical installations, and research. An offshoot of the program is the Creative Coding \& Immersive Technologies Certification, which focuses on the conception, design, and creation/implementation of new technology in media. The certification is hands on and project based, in which students work both independently and collaboratively with each other and those outside of the campus. In addition to the general overlap between PCC's Music and Sonic Arts Program and the EHMS, (i.e., members of the EHMS being students at PCC), the program has resulted in a number of developments that some members of the EHMS are involved in. Members of the EHMS, in conjunction with PCC, have created something they've dubbed "Unity Gain": wa high-density loudspeaker array (HDLA) that allows composers to showcase 3-dimensional music in 32 channels (in contrast to the more typical two channels of stereo sound or the 6-7 channels of surround sound). I talked to a number of participants about how critical PCC has been in their and others' development as artists embedded in the EHMS. Every participant that was involved with the program had either full or

\footnotetext{
${ }^{13}$ Webteam@pcc.edu. (n.d.). Portland Community College. Retrieved from https://www.pcc.edu/programs/music-and-sonic-arts/.
} 
part time employment in a field which utilized their degree in day jobs that complimented the EHMS. One participant went into detail regarding both the material and institutional boon that PCC has been:

The space I have to make music in is PCC. I have a lab with the 32 speakers. I have the interactivity lab at PCC: soldering irons, synths, wires, lights, controllers, resistors, computers, projectors... For installation work I borrow from PCC. I've used their space to sit and code. Once we all lose access to this, if we do, we're going to have to find a space to congregate, have workshops, actually be able to do all this stuff. I live in a studio, and I don't have the space for this stuff. If we don't have PCC, what we need is some sort of maker or hacker space.

Participants noted that the 32-channel sound system is the only of its kind in the United States at an open access institution, in which anyone in the program can utilize the system. One participant I talked to noted that the program catalyzed their career as an electronic artist and musician, stating that as a result, they were able to create installations at PICA, Disjecta, S1 and the Portland Art Museum.

Creative Music Guild

The Creative Music Guild occupies a unique place in the landscape of the EHMS, as it has no direct connection with the production or consumption of electronic music, instead promoting experimental and acoustic improvised music through concerts, workshops, and other events that bring together local and internationally recognized musicians and performers, as well as audiences and 
students of all age groups. The Creative Music Guild has been operating as a non-profit for over twenty years, run by a board of directors and committee members made of local performers, educators, music makers, and volunteers. There is an unlikely and interesting overlap between the subculture of the Creative Music Guild and the EHMS, just as other seemingly-at-odd subcultures overlap (e.g., punk and hip-hop's value on rebellion or authenticity). The Creative Music Guild has often occupied the territory of cultural music production that's outside the mainstream in Portland, and members in the EHMS have found the non-profit to be helpful for networking, performance opportunities, improvisation summits, and various music series. As one participant mentioned:

Even though the Creative Music Guild isn't really composed of electronic musicians, they are so open to collaborative and experimental workshops and performances. I would say more than any other 'acoustic' music scene, everyone there is really interested and excited to incorporate electronic music, especially modular synth and stuff like that, than about anyone else.

Because of its long standing history in the Portland area, and its success surviving as a relatively small, niche institution focusing on cultural production, many members of the EHMS expressed the value that the CMG and its members added to the EHMS. Venues that CMG members performed at, or record stores and labels that carried members of the CMG, were often accessible and open to members of the EHMS, not because of the type of music members of the EHMS played, (which is stylistically different than the jazz or improvisational music 
performed by members of the $\mathrm{CMG}$ ), but because of the values that both subcultures emphasize, such as experimentation, community, resistance to mass-marketability, and "deep" listening experiences. ${ }^{14}$

\section{Pacific Northwest College of Art}

The Pacific Northwest College of Art (PNCA) is a private fine arts and design college established in 1909. The school grants bachelor of fine arts degrees and graduate degrees and enrolls about 500 students, but the cultural presence of PNCA, especially for visual art and music, cannot be overstated. PNCA actively participates in Portland's cultural life through a public program of exhibitions, lectures, and internationally recognized visual artists, designers, and creative thinkers. The majority of members of the EHMS that I interviewed who were around during the solidification of Portland's experimental electronic music scene said that they found out about venues and artists like S1 through their connection to PNCA, either as a student, or because they were friends with students or faculty there. While there are no formal institutional connections between S1 and PNCA, the individual and community connections are significant. PNCA has hosted a number of events that overlap with the EHMS, including: S1 gallery information sessions ${ }^{15}$; the work of Sidony O'Neal, who had a residency at S1's synth library; the art of DJ Manuel Arturo Abreu ${ }^{16}$;

\footnotetext{
${ }^{14}$ Oliveros, P. (2005). Deep listening: A composer's sound practice. I Universe.

${ }^{15} \mathrm{~S} 1$ Gallery Session. (n.d.). Retrieved from https://cal.pnca.edu/e/1602.

${ }^{16}$ Nat Turner Project : Sidony O'Neal + Manuel Arturo Abreu. (n.d.). Retrieved from https://cal.pnca.edu/e/1942.
} 
Inging/Harmonistasis by Ben Glass, an interactive sound installation ${ }^{17}$; the "SIX" series, a live, experimental surround sound speaker performance set ${ }^{18}$, and countless other events. PNCA is also important for the EHMS not only due to the network connections it provides, but explicitly because of its educational programs offered. One such program is the Video and Sound Bachelor of Fine Arts, in which students work on interdisciplinary projects including immersive audiovisual performances, interactive installations, and more. ${ }^{19}$

The institution of PNCA reifies in Portland what Danto (1964) called an "artworld". There is little that is aesthetically intrinsic to the events and art shown at PNCA and music made by members of the EHMS, besides maybe experimentation. Instead, the connection between PNCA and the EHMS is primarily sociological, and perhaps value driven: students and faculty at PNCA are open to multi-modal and experimental forms of art and media (as opposed to the static work of fine art or well established traditions of classical music). For these reasons, the overlap between PNCA and EHMS is strong, and dynamic. PNCA also provides the physical and institutional capacity for members of the EHMS to translate their social and cultural capital into what Bourdieu (1986) recognized as cultural institutional capital. A number of educators at PNCA have essentially taken the path from electronic and experimental musician or artist to

\footnotetext{
${ }^{17}$ Inging/Harmonistasis (n.d.). Retrieved from: https://cal.pnca.edu/e/1854.

${ }^{18}$ SIX. (n.d.). Retrieved from: https://events.pnca.edu/e/2651.

${ }^{19}$ PNCA Video Sound. (n.d.). Retrieved from https://pnca.edu/academics/bfa/video-sound.
} 
college educator, offering insight, advice, and other educational resources to members in the EHMS that are likewise trying to solidify their institutional capital, as one participant told me:

Even if you don't go to school there, it's a pretty big deal. You have people like Seth Nehil who has worked with Olivia Blocke and got started doing electronic music. [Carl] Diehl has also had a really varied past and body of work, and that kind of frames things for you as an up and coming artist. I'm going to make music regardless, but I look at places like PNCA or PCC and think "ok", that's a path I can take.

The institutions connected to the EHMS do more than just provide cultural amenities for members of the EHMS, and the greater Portland public at large: they provide the necessary tools for individuals to create cultural products, not just consume them. Individual participants are limited in terms of knowledge, resources, and the processes that are required for music making, or cultural production more generally, but communities and institutions mitigate these limitations, and allow individuals to overcome them. The high concentration of prominent institutions throughout Portland are clearly a major reason that the EHMS and the cultural output of its members exist as such, and have been able to move from performing at the plethora of house and DIY-oriented venues to more professional outlets like Disjecta or PICA. 


\section{Chapter 5: Conclusion}

This study examined why the EHMS is a vibrant and thriving subculture in Portland, how members of this subculture interact with and produce aspects of the local cultural economy, and the factors that mediate the output of cultural production for members of the EHMS at the individual and institutional level. The subculture of the EHMS thrives because of the ability of members to pursue their art with relative freedom, and the ability to support themselves through part time work and flexible career paths that might not be sustainable for individuals in more expensive urban areas. Adorno and Horkheimer (1944) and Hirksckop (1989) argue that the aspect of commercialization, and creating art and music for profit, necessarily limits the scope, autonomy, and creativity of cultural production. Hebdige (1979), on the other hand, argues that commercialization and pursuing music for profit is irrelevant for artists and musicians. Consistent with this approach, artists in the EHMS generally are not concerned with making music for profit, however artists are also not primarily concerned with their art being interpreted through the act of consumption.

Bourdieu's framework provides a way to understand the culturally productive capacities of individuals within a subculture through its analysis of various factors affecting cultural production for given individuals. Bourdieu's approach of analyzing cultural production offered insight into one of the most 
critical reasons for the success of the EHMS in Portland: the dense and significant network of culturally focused institutions in the close in urban area.

While most participants noted that they are not making enough money to sustain themselves purely from their art or music, they also explicitly stated that the resources and institutions of Portland allow them to effectively pursue that avenue. This is consistent with research showing that urban communities that have strong cultural clusters, more specifically, concentrations of nonprofit and arts organizations, commercial cultural firms, and capacities for audiences and cultural consumers, lend themselves to cultural production by way of artist involvement (Stern and Seifert, 2007). These cultural clusters, which are partly dependent on the institutional capacities of urban areas, are distinct from cultural amenities, as they are the cause of cultural amenities (Scott,1996; Mommaas 2004; Gibson and Kong, 2005). Further, the dense network of institutions connected to the EHMS allow participants of the subculture to improve the quality and increase the output of their work. Clusters of cultural production are also associated with higher levels of regional and civic engagement, and decreases in poverty rates, which should mitigate concerns of creative economy boosterism. Urban areas, and Portland specifically, don't need to focus on bolstering the creative economy or cultural production simply to make the city more attractive to tourists or young college educated migrants: clusters of cultural production should be a boon to citizens and artists of the city as well (Cohen, 2003). Many 
scholars have examined consumer-oriented cultural clusters as a way of bolstering cultural production (Evans, 2004), while Montgomery (2004) analyzed what aspects of the built environment contributes to geographic areas of cultural production. While these approaches are necessary and valid, understanding cultural production modalities that are highly in flux, distributed, and technical, such as contemporary electronic music or video production, requires a thorough analysis and understanding of the agents and institutions that are at work in the cultural clusters of a given city.

The institutional capacity of Portland as it relates to the EHMS provides an opportunity for policy exploration and experimentation in the area of urban cultural production related that has yet to be fully understood by researchers and planners. Many individuals are moving to and staying in Portland because of the cultural amenities, and Portland is in a unique position and crossroads as a sort of tertiary city in the United States. Every participant mentioned that Portland is a prime city to get started as a cultural producer, but about half of them expressed sentiments of outgrowing Portland, or hitting a kind of cultural glass ceiling, which would require them to eventually move to New York, Los Angeles, or cities abroad like Berlin. Interestingly, every participant, with the exception of one who planned on moving to Los Angeles, stated that they did not want to move per se, but the lack of advancing their artistic or professional career as an artist or cultural producer dictated that eventually they may have to. In short, Portland 
might be experiencing a kind of "brain drain" at the more advanced levels of cultural production. The dense institutional capacity of Portland lends itself to a kind of competitive advantage to other cities of similar size and urban layout. Participants generally were not interested in the implementation of explicit "art and culture" policies that the local or regional level. Instead, participants needed more time, money and space in order to effectively contribute to the cultural economy, meaning future planners and researchers should investigate how to implement social safety net policies that either directly or indirectly benefit local cultural producers and the public at large, such as competitive local wages, tenant protection laws, and public healthcare options.

The findings of this study suggest that one of, if not the most critical aspect to having vibrant cultural (or musical) economies is the availability and affordability of space for burgeoning musicians and artists. Space in this sense does not merely refer to affordable housing for musicians and artists, but an availability of performance venues at all levels of artistery, from amateur to professional. It is true that technological proliferation and a decline in hardware and instrument costs have led to an explosive rise in "bedroom" musicians and producers, but these individuals still need venues to perform and practice their craft in urban environments, especially with receptive audiences. My findings indicate that Portland's surplus of housing stock offers a jumping off point for nascent artists, who then refine their skills in the professional and institutional 
environment that Portland offers. Planners focusing on bolstering the cultural economy need to carefully examine the urban environment to find what geographic factors are helping or hindering cultural producers in various milieus. Artists do not necessarily need to live in a city with a surplus of housing stock to make the jump from dilettante to performer, but they do need spaces to play and perform in urban areas that will draw audiences in some capacity. These spaces might be local bars and restaurants, hotel lobbies, art galleries, repurposed manufacturing buildings, or even public parks. Planners and researchers aiming to aid the cultural economy need to pay close attention to the geographic particulars of their urban environment, and the subcultural economies bubbling below the surface.

The fundamental purpose of this study has been to understand the EHMS, how cultural musical production happens in this particular subculture, and how these findings can be generalized to cultural production in the urban environment. The phenomenological and ethnographic research on the EHMS demonstrate that the key factors that affect the output of cultural producers in the EHMS are the availability of performance and practice space, receptivity of audiences, community support, and well developed and culturally focused institutional networks. To understand specific cultural production milieus, future researchers should examine the urban environment that artists, musicians and 
makers find themselves in, especially the institutional capacity for development and success, both artistically, and commercially. 


\section{$\underline{\text { References }}$}

Anderson, B., Morton, F., \& Revill, G. (2005). Practices of music and sound.

Becker, H. (1982). S., Art Worlds, Berkeley.

Bourdieu, P. (2013). Distinction: A social critique of the judgement of taste. Routledge.

Bell, T. (1998). Why Seattle? An examination of an alternative rock culture hearth. Journal of Cultural Geography, 18(1), 35-47.

Bille, T., \& Schulze, G. G. (2006). Culture in urban and regional development. Handbook of the Economics of Art and Culture, 1, 1051-1099.

Borrup, T. (2006). The creative community builder's handbook: How to transform communities using local assets, art, and culture. Fieldstone Alliance.

Bourdieu, P. (1986). The forms of capital. Cultural theory: An anthology, 1, 81-93.

Bourdieu, P. (1993). The field of cultural production: Essays on art and literature. Columbia University Press.

Braun, V., \& Clarke, V. (2006). Using thematic analysis in psychology. Qualitative research in psychology, 3(2), 77-101.

Brennan-Horley, C., \& Gibson, C. (2009). Where is creativity in the city? Integrating qualitative and GIS methods. Environment and Planning A, 41(11), 2595-2614.

Carney, G.O. (1978). The sounds of people and places: readings in the geography of music. Washington, DC: University Press of America.

Cohen, S. (1995). Sounding out the city: music and the sensuous production of place. Transactions of the Institute of British Geographers 20 (4), pp. 434-446.

Collins, N., \& d'Escriván, J. (Eds.). (2017). The Cambridge companion to electronic music. Cambridge University Press.

Connell, J. and Gibson, C. (2003). Sound tracks: popular music, identity and place. London: Routledge.

Connell, J. and Gibson, C. (2004). World music: deterritorializing place and identity. Progress in Human Geography 28 (3), pp. 342-361.

Cosgrove, S. (1998). Detroit Techno. Techno! The new dance Sound of Detroit.

Currid, E., \& Williams, S. (2009). The geography of buzz: art, culture and the social milieu in Los Angeles and New York. Journal of Economic Geography, 10(3), 423-451.

Currid, E. (2007). How art and culture happen in New York: Implications for urban economic development. Journal of the American Planning Association, 73(4), 454-467. 
Dadler, S. (1993). Consumer Electronics Companies: Technological Change and the Music Industry. The Place of Music: Culture and Economy conference

Danto, A. (1964). The artworld. The journal of philosophy, 61(19), 571-584. Chicago

Davies, S. R. (2017). Hackerspaces: making the maker movement. John Wiley \& Sons.

DiMaggio, P. (2006). Nonprofit organizations and the intersectoral division of labor in the arts. The nonprofit sector: A research handbook, 2, 432-461.

Dooley, K. (2001). Social research methods. In 4th ed. Upper Saddle River, NJ.

Doussard, M., Schrock, G., Wolf-Powers, L., Eisenburger, M., \& Marotta, S. (2018). Manufacturing without the firm: Challenges for the maker movement in three US cities. Environment and Planning A: Economy and Space, 50(3), 651-670.

Dwyer C., Beavers K., and Hodgson K. (2011). How the Arts and Culture Sector Catalyzes Economic Vitality. American Planning Association.

Eco, U. (1976). A theory of semiotics (Vol. 217). Indiana University Press.

Evans, G. (2002). Cultural planning: an urban renaissance? Routledge.

Evans, G. (2005). Measure for measure: Evaluating the evidence of culture's contribution to regeneration. Urban Studies 42 (5/6): 959-83.

Florida, R. (2002). Bohemia and economic geography. Journal of economic geography, 2(1), 55-71.

Florida, R. (2014). The Rise of the Creative Class-Revisited: Revised and Expanded. Basic Books (AZ).

Florida, R., \& Jackson, S. (2010). Sonic city: The evolving economic geography of the music industry. Journal of Planning Education and Research, 29(3), 310-321.

Franck, K., \& Stevens, Q. (2013). Loose space: possibility and diversity in urban life. Routledge.

Frith, S. (1992). The Cultural Study of Popular Music. Cultural Studies. New York and London: Routledge, 1992.

Guest, G., Bunce, A., \& Johnson, L. (2006). How many interviews are enough? An experiment with data saturation and variability. Field methods, 18(1), 59-82.

Gibson, C., \& Kong, L. (2005). Cultural economy: a critical review. Progress in human geography, 29(5), 541-561.

Gibson, C., and L. Kong. (2005). Cultural economy: A critical review. Progress in Human Geography 29 (5): 541-61. 
Gibson, C. (2005). Recording studios: relational spaces of creativity and the city. Built Environment 31 (3), pp. 192-207. Gibson, C and Connell, J. (2005). Music and tourism. Bristol: Channel View Publications.

Ginsburgh, V. A., \& Throsby, D. (2014). Handbook of the economics of art and culture: volume 2.

Glaser, B. G., \& Strauss, A. L. (2017). Discovery of grounded theory: Strategies for qualitative research. Routledge.

Goodling, E., Green, J., \& McClintock, N. (2015). Uneven development of the sustainable city: Shifting capital in Portland, Oregon. Urban Geography, 36(4), 504-527.

Grodach, C. (2008). The local arts planning system: Current and alternative directions. New Village Commons, 3.

Halfacree, K. H. and Kitchin, R. M. (1996). 'Madchester rave on': placing the fragments of popular music. Area 28 (1), pp. 47-55.

Harvey D. (1989) The Urban Experience (Baltimore: The John Hopkins University Press).

Harvey, D. (1996). Justice, Nature and the Geography of Difference. Oxford, UK: Blackwell Publishing.

Harvey, D. (2008). The right to the city. The City Reader, 6, 23-40.

Hebdige, D. (1979). Subculture: The Meaning of Style. London: Routledge. Held at University College, London, 13-14 September 1993.

Heying, C. (2010). From Brews to Bikes: Portland's Artisan Economy. Portland, Oregon, Portland State University: Ooligan Press.

Horkheimer, M., \& Adorno, T. W. (1944). The culture industry: Enlightenment as mass deception.

Hracs, B. (2015). Cultural Intermediaries in the Digital Age: The Case of Independent Musicians and Managers in Toronto. Regional Studies. Volume 49 (3): 461-75.

Hudson, R. (1993). Making Music Work: An Alternative Route to Local Economic Regeneration? The Place of Music: Culture and Economy conference held at University College, London, 13-14 September 1993.

Hudson, R. (1995). Making music work? Alternative regeneration strategies in a deindustrialized locality: the case of Derwentside. Transactions of the Institute of British Geographers 20 (4), pp. 460-473.

Jurjevich, J. R., \& Schrock, G. (2012). Is Portland really the place where young people go to retire? Migration patterns of Portland's young and college-educated, 1980-2010. Metropolitan Knowledge Network.

Kearns G., Philo C. (1993). Selling Places: the City as Cultural Capital, Past and Present. Oxford: Pergamon. 
Kong, L. (1995). Popular music in geographical analyses. Progress in Human Geography 19 (2), pp. 183-198.

Krims, A. (2000). Rap music and the poetics of identity. Cambridge: Cambridge University Press.

Krims, A. (2002). Rap, race, the 'local', and urban geography in Amsterdam. In: Young, R. (ed.) Music, popular culture, identities. Amsterdam: Rudopi, pp. 165- 179.

Krims, A. (2012). Music and urban geography. Routledge.

Landry, C. (2003). The Creative City: A Toolkit for Urban Innovators. London: Earthscan

Landy C. (1996). The Creative City in Britain and Germany. London: Anglo-German Foundations for the Study of Industrial Society.

Larsen, J. and Urry, J. (2011). The Tourist Gaze 3.0. London: Sage.

Lazzeroni, M., Bellini, N., Cortesi, G., \& Loffredo, A. (2013). The territorial approach to cultural economy: new opportunities for the development of small towns. European planning studies, 21(4), 452-472.

Leyshon, A., Matless, D. and Revill, G. (1995). The place of music. Transactions of the Institute of British Geographers. 20 (4), pp. 423-433.

Lloyd, R. (2010). Neo-bohemia: Art and commerce in the postindustrial city. Routledge.

Logan, J. R., and H.L. Molotch. (1987). Urban Fortunes: The Political Economy of Place. Berkeley and Los Angeles: University of California Press.

London, J. (2017). Portland Oregon, Music Scenes, and Change: A Cultural Approach to Collective Strategies of Empowerment. City \& Community, 16(1), 47-65.

Maxwell, J. A. (1996). Qualitative research design: An interactive approach. Thousand Oaks, CA: Sage.

Mager, C. (2007). HipHop, Musik und die Artikulation von Geographie. Stuttgart: Steiner.

Markusen, A., Gilmore, S., Johnson, A., Levi, T., and Martinez, A. (2006). Crossover: How artists build careers across commercial, nonprofit and community work. Project on Regional and Industrial Economics, University of Minnesota, Minneapolis: MN

Markusen, A., Wassall, G., DeNatale, D., and Cohen, R. (2008). Defining the Creative Economy: Industry and Occupational Approaches. Economic Development Quarterly. Volume 22 (1): 24-45.

Markusen, A. and Schrock, G. (2006). The artistic dividend: Urban artistic specialization and economic development implications. Urban Studies. Volume 43 (10): 1661-1686.

McCracken, G. (1986). Culture and consumption: A theoretical account of the structure and movement of the cultural meaning of consumer goods. Journal of consumer research, 13 (1): 71-84. 
Miles, M. B., \& Huberman, A. M. (1994). Qualitative data analysis: An expanded sourcebook. Sage.

Miles M., Hall T., Borden I. (2000). City Cultures Reader (London: Routledge).

Mommaas, H. (2004). Cultural clusters and the post-industrial city: towards the remapping of urban cultural policy. Urban studies, 41(3), 507-532.

Montgomery, J. (2003). Cultural quarters as mechanisms for urban regeneration. Part 1: Conceptualising cultural quarters. Planning, practice \& research, 18(4), 293-306.

Oliveros, P. (2005). Deep listening: A composer's sound practice. IUniverse.

Perl, J. (2005). New art city: Manhattan at mid-century. New York: Alfred A. Knopf.

Pinch, T. and Bijsterveld, K. (2004). Sound studies: new technologies and music. Social Studies of Science 34 (5), pp. 635-648.

Power, D. and Hallencreutz, D. (2002). Profiting from creativity? The music industry in Stockholm, Sweden and Kingston, Jamaica. Environment and Planning A 34 (10), pp. 1833-1854.

Sadler, D. (1997). The global music business as an information industry: reinterpreting economies of culture. Environment and Planning A 29 (11), pp. 1919-1936.

Scott, A. (2000). The Cultural Economy of Cities. London: Sage.

Scott, J. (2004). Cultural-Products Industries and Urban Economic Development Prospects for Growth and Market Contestation in Global Context. Urban Affairs Review, 29, (4)

Seifert, S. and Stern M. (2005). 'Natural' cultural districts: Arts agglomerations in metropolitan Philadelphia and implications for cultural district planning. Working Paper \#2005-2, Social Impact of the Arts Project, University of Pennsylvania.

Smith, S. J. (1994). Soundscape. Area 26 (3), pp. 232-240.

Smith, S. J. (1997). Beyond geography's visible worlds: a cultural politics of music. Progress in Human Geography 21 (4), pp. 502-529.

Stern, Mark J., and Susan C. Seifert. (2007). Cultivating "natural" cultural districts. Philadelphia: The Reinvestment Fund.

Tacchi, J. A., Hearn, G. N., \& Ninan, A. (2004). Ethnographic action research: A method for implementing and evaluating new media technologies. In Information and communication technology: Recasting development: 253-274. BR Publishing Corporation.

Vang, J., and C. Chaminade. (2007). Cultural clusters, global-local linkages and spillovers: Theoretical and empirical insights from an exploratory study of Toronto's film cluster. Industry and Innovation 14 (4): 401-20. 
Veblen, T. (2017). The theory of the leisure class. Routledge.

Walker, C. (2007). Artist Space Development Financing. Leveraging Investments in Creativity. Urban Institute.

Watson, A. (2008). Global music city: knowledge and geographical proximity in London's recorded music industry. Area 40 (1), pp. 12-23.

Weber, M. (2002). The Protestant ethic and the" spirit" of capitalism and other writings. Penguin.

Wolf-Powers, L., Doussard, M., Schrock, G., Heying, C., Eisenburger, M., \& Marotta, S. (2017). The maker movement and urban economic development. Journal of the American Planning Association, 83(4), 365-376.

Zukin, S. (1982). Loft Living: Culture and Capital in Urban Change. Baltimore, MD: Johns Hopkins University Press.

\section{Appendix}

\section{Table 1}

Institutions and Organizations connected to the EHMS

\begin{tabular}{|c|c|c|c|c|c|c|}
\hline Institution & $\begin{array}{l}\text { Institution } \\
\text { Type }\end{array}$ & Founded & Budget* & Function & $\begin{array}{l}\text { EHMS } \\
\text { Function }\end{array}$ & Location \\
\hline $\begin{array}{l}\text { Portland } \\
\text { Community } \\
\text { College }\end{array}$ & Public & 1961 & $\begin{array}{l}\$ 26 \text { million for } \\
\text { Cascade } \\
\text { Campus }^{20}\end{array}$ & Public College & $\begin{array}{l}\text { Education, } \\
\text { Hardware, } \\
\text { Networking }\end{array}$ & Multiple \\
\hline S1 & Private & 2014 & & $\begin{array}{l}\text { Events; } \\
\text { Workshops }\end{array}$ & $\begin{array}{l}\text { Music Venue; } \\
\text { Workshops; } \\
\text { Education; } \\
\text { Networking; } \\
\text { Hardware }\end{array}$ & SE Portland \\
\hline $\begin{array}{l}\text { Creative Music } \\
\text { Guild }\end{array}$ & Non-Profit & 1991 & & Events & $\begin{array}{l}\text { Education, } \\
\text { Performance, } \\
\text { Networking }\end{array}$ & NE Portland \\
\hline $\begin{array}{l}\text { Turn, Turn, } \\
\text { Turn }\end{array}$ & Private & & & & Performance & NE Portland \\
\hline X-Ray & Non-Profit & 2012 & & Radio Station & Airtime & N Portland \\
\hline $\begin{array}{l}\text { Freeform } \\
\text { Portland }\end{array}$ & Non-Profit & 2016 & & Radio Station & Airtime & N Portland \\
\hline
\end{tabular}

${ }^{20}$ 2017-2019 Biennium Adopted Budget. (n.d.). Retrieved from https://www.pcc.edu/about/administration/documents/2017-19-budget.pdf 


\begin{tabular}{|c|c|c|c|c|c|c|}
\hline $\begin{array}{l}\text { Regional Arts } \\
\text { and Culture } \\
\text { Council }\end{array}$ & Non-Profit & & $\$ 16$ million ${ }^{21}$ & & & \\
\hline $\begin{array}{l}\text { Pacific } \\
\text { Northwest } \\
\text { College of Art }\end{array}$ & $\begin{array}{l}\text { Private Fine } \\
\text { Arts }\end{array}$ & 1909 & $\$ 14.7$ million ${ }^{22}$ & Private College & $\begin{array}{l}\text { Education, } \\
\text { Hardware, } \\
\text { Networking }\end{array}$ & NW Portland \\
\hline Open Signal & Non-Profit & 2017 & $\$ 2.5$ million & Media & $\begin{array}{l}\text { Education, } \\
\text { Hardware, } \\
\text { Networking }\end{array}$ & NE Portland \\
\hline $\begin{array}{l}\text { Portland State } \\
\text { University }\end{array}$ & Public & 1946 & $\$ 73$ million ${ }^{23}$ & Public College & $\begin{array}{l}\text { Education, } \\
\text { Networking }\end{array}$ & SW Portland \\
\hline XChurch & Private & & & Events & $\begin{array}{l}\text { Hardware, } \\
\text { Performance }\end{array}$ & NE Portland \\
\hline Holocene & Private & 2003 & & Events & Music Venue & SE Portland \\
\hline Ivon House & Private & 2018 & & Events & Music Venue & SE Portland \\
\hline $\begin{array}{l}\text { Boathouse } \\
\text { Microcinema }\end{array}$ & Private & 2017 & & Events & Music Venue & N Portland \\
\hline $\begin{array}{l}\text { Leaven } \\
\text { Community }\end{array}$ & Private & & & Events & Music Venue & NE Portland \\
\hline $\begin{array}{l}\text { Killingsworth } \\
\text { Dynasty }\end{array}$ & Private & & & Events & Music Venue & NE Portland \\
\hline Liquor Store & Private & & & Events & Music Venue & SE Portland \\
\hline Odyssey & Private & & & Events & Music Venue & N Portland \\
\hline Ace Hotel & Private & & & Events & Music Venue & SW Portland \\
\hline $\begin{array}{l}\text { Portland } \\
\text { Institute of } \\
\text { Contemporary } \\
\text { Art }\end{array}$ & Private & & & $\begin{array}{l}\text { Contemporary } \\
\text { Art Center }\end{array}$ & $\begin{array}{l}\text { Networking, } \\
\text { Performance }\end{array}$ & NE Portland \\
\hline Disjecta & Non-Profit & & & $\begin{array}{l}\text { Contemporary } \\
\text { Art Center }\end{array}$ & Performance & N Portland \\
\hline Specs Records & Private & & & Record Store & Record Store & N Portland \\
\hline $\begin{array}{l}\text { Little Axe } \\
\text { Records }\end{array}$ & Private & 2011 & & Record Store & Record Store & NE Portland \\
\hline $\begin{array}{l}\text { Musique } \\
\text { Plastique }\end{array}$ & Private & & & Record Store & Record Store & NE Portland \\
\hline Beacon Sound & Private & & & Record Store & $\begin{array}{l}\text { Record Store; } \\
\text { Music Venue }\end{array}$ & NE Portland \\
\hline Control Voltage & Private & & & Merchandise & Workshops & NE Portland \\
\hline
\end{tabular}

${ }^{21}$ RACC 2018 Annual Report. Retrieved from

http://annualreports.racc.org/wp-content/uploads/2018/12/RACC-Final-FS-1.pdf

${ }^{22}$ As of June 30, 2011. "U.S. and Canadian Institutions Listed by Fiscal Year 2011 Endowment Market Value and

Percentage Change in Endowment Market Value from FY 2010 to FY 2011" (PDF).

23 "Profile". Portland State University. Retrieved February 1, 2019. Retrieved from:

https://www.pdx.edu/profile/snapshot-portland-state 
* Budget only listed if exceeds $\$ 100,000$ per year

\title{
Interview Guide
}

\author{
Individual History and Background
}

- Tell me about yourself. How are you involved in making music?

- How did you get started?

- What do you do for work? [Economic]

$\circ \quad$ Is there any relation between your work and music? [Economic]

- Do you make music for commercial reasons? (Individual) [Economic / Artistic]

- Do you have enough time or money to create what you want to? [Economic]

- Where do you make music?

$\underline{\text { Social Capital and Subcultural Involvement }}$

- How did you learn how to make music? Did anyone teach you? Where do you perform?

- Do you get paid to perform? [Economic]

- Do you know others that are making similar music? If so, who?

- Does knowing other artists or producers affect your own success? [Economic / Artistic]

- Are you concerned with other's success? [Economic / Artistic]

- Are their tensions between others success and your own, or do you feel like their success is or would be beneficial to you? [Economic / Artistic]

$\underline{\text { Institutional Analysis }}$

- Are there places or spaces in Portland that you do or can learn how to make the music you make?

$\circ$ If so, what are they? Do they cost anything? [Economic]

- What institutions are you involved in, related to your music? This could be local colleges non-profits, or even private businesses.

- What are the functions of these institutions?

- How would you say they impact your artistic or commercial success? [Economic / Artistic]

- Could you or others be successful without these institutions? [Economic / Artistic]

- Would you say that some are more useful than others?

- Is there anything about Portland that makes you want to make music here?

- Would you like to make music in a different city? Which? And why? 


\title{
Final Thematic Codes
}

\author{
$\underline{\text { Geographic }}$
}

Portland, SE, NE, SW, NW, NoPo, inner, outer, LA, NYC, Brooklyn, Chicago, Pittsburgh, Philadelphia, CA, studio, space, west coast, east coast

\section{$\underline{\text { Cultural Production Factors }}$}

capital, rent, monetary, money, time, work, labor, full time, part time, institutional, institution, network, networking, social, socializing, motivation, economic, social, institutional, commercial, artistic

$\underline{\text { Institutions }}$

PICA, PNCA, Xchurch, S1, Leaven Community, Beacon Sound, Ivon House, Turn Turn Turn, The Know, Rave, Odyssey, The Liquor Store, PSU, XRAY, Freeform, PCC, Creative Music Guild, RACC, Open Signal, Holocene, Ace Hotel, Disjecta

\section{Relating to the EHMS}

synth, build, workshop, maker, hacker, speakers, laptop, audience, consumption, production, culture, art, visual, programming, education, learn

\section{Research}

contrast, compared, bourdieu, adorno, hebdige, theory, research question, qualitative, quantitative, demographic, 